Nevşehir Bilim ve Teknoloji Dergisi Cilt 4(2) 44-74 2015

DOI: $10.17100 /$ nevbiltek.211031

URL: http://dx.doi.org/10.17100/nevbiltek.211031

\title{
Zeytinyağı Üretim Atıksularının Özellikleri, Çevresel Etkileri ve Arıtım
}

Teknolojileri

\author{
Müslün Sara TUNÇ ${ }^{1 *}$, Ayhan ÜNLÜ ${ }^{1}$ \\ ${ }^{1}$ Fırat Üniversitesi Mühendislik Fakültesi Çevre Mühendisliği Bölümü, Elazı̆̆
}

$\ddot{O} \mathbf{z}$

Zeytinyağı üretim atıksuları; mevsimsel üretim, tesislerin geniş arazilere yayılması, yüksek organik yük gibi çeşitli faktörlerden dolayı zeytinyağı üretimi yapan Akdeniz Ülkelerinde ciddi bir çevresel problemdir. Bu atıksuların miktarı ve kirlilik yükü kullanılan üretim prosesine ve işletim koşullarına bağlı olarak değişmektedir. Organik madde, askıda katı madde, yağ ve gres içerikleri oldukça yüksektir. Yüksek organik madde ve toksik maddeler içermesi, sezonluk üretim yapılması ve üretim sezonunun birkaç ay devam etmesi bu atıksuların arıtımını zorlaştırmaktadır. Çevreye deşarj edilen arıtılmamış veya yetersiz şekilde arıtılmış zeytinyağı üretim atıksuları çevre üzerinde olumsuz etkilere neden olmaktadır. Çevre üzerindeki olumsuz etkilerini önlemek ve yüksek kirlilik içeren bu atıksuları arıtmak için pek çok arıtma yöntemi araştırılmış ve geliştirilmiştir. Bu çalışmada zeytinyağı üretim atıksuların arıtımı üzerine yapılan çalışmalar incelenmiştir. Literatür ışığında zeytinyağı üretim prosesleri, üretim sonrasında oluşan atıksuyun bileşimi ve bu atıksuların çevresel etkileri sunulmuş ve atıksu arıtımında kullanılan biyolojik, fizikokimyasal ve ileri oksidasyon yöntemleri derlenmiştir.

Anahtar Kelimeler: Zeytinyağı atıksuları, biyolojik yöntemler, fizikokimyasal yöntemler, ileri oksidasyon yöntemleri

\section{Characteristics of Olive Oil Wastewater, Its Environmental Effects and Treatment Technologies}

\begin{abstract}
Olive oil manufacturing wastewater is a serious environmental problem in the Mediterranean regions due to several factors such as seasonal production, distribution over large areas of mills, high organic load. Amount and pollutant load of this wastewater changes depending production process used and operational conditions. Organic matter, suspended solid matter, oil and grease contents of this wastewater are quite high. Treatment of olive oil wastewaters becomes difficult due to high organic matter, seasonal production and short production season. Untreated or insufficiently treated olive oil wastewater discharged to the environmental causes negative impacts on the envorinmental. Various treatment methods were investigated and developed to treat of this wastewater containing high pollutant and to prevent negative impacts on the environmental. In this study, researchs performed on treatment of olive oil wastewater were examined. Olive oil production processes, composition of wastewater generated after production process and its environmental impacts were presented. Biological methods, physico-chemical methods and advanced oxidation methods used for treatment of this wastewater were reviewed.
\end{abstract}

Keywords: Olive oil wastewater, biological methods, physico-chemical methods, advanced oxidation methods

*e-mail:saratunc@ firat.edu.tr 


\section{Giriş}

Zeytin ağacı yılda 15 ve $40 \mathrm{~kg}$ arasında zeytin vermektedir. Dünya çapında 2002 yılında, çoğunluğu Akdeniz Ülkelerinde olan 750 milyon verimli zeytin ağacından üretilen zeytinyağı üretimi 2 546306 ton olmuştur. Toplam zeytinyağı üretiminin \%97'sini sadece Akdeniz Ülkeleri üretmektedir. En büyük zeytinyağı üreticileri İspanya, İtalya, Yunanistan, Türkiye, Tunus, Portekiz, Fas ve Cezayir'dir. Akdeniz havzası dışında Ortadoğu, Amerika Birleşik Devletleri, Arjantin ve Avustralya'da da zeytinler yetiştirilmektedir [1]. Türkiye dünyada zeytin üretiminde altıncı sıradadır [2]. Zeytin meyvesi Ekim ayında olgunlaşmaya başlamakta ve Aralık ayına kadar yavaşça siyaha dönüşmektedir. Toplanılan zeytinler sofra zeytini olarak tüketilmekte veya yağ üretimine gönderilmektedir. Zeytin meyvesi \%30 lipitler, \%20 karbonhidratlar ve \%50 sistemik su içeren katı meyve çekirdeğine sahiptir [3]. Zeytinlerin bileşimi Tablo 1'de verilmiştir [4].

Tablo 1. Zeytinlerin Bileşimi [4].

\begin{tabular}{llll}
\hline Bileşenler & Meyve özü (\%) & Çekirdek (\%) & Tohum (\%) \\
Su & $50-60$ & 9.3 & 30 \\
Yağ & $15-30$ & 0.7 & 27.3 \\
Azot içeren bileşikler & $2-5$ & 3.4 & 10.2 \\
Şeker & $3-7.5$ & 41 & 26.6 \\
Selüloz & $3-6$ & 38 & 1.9 \\
Mineraller & $1-2$ & 41 & 1.5 \\
Polifenoller & $2-2.25$ & 0.1 & $0.5-1$ \\
Diğerleri & - & 3.4 & 24 \\
\hline
\end{tabular}

Üç fazlı sürekli santrifüj proses ve klasik kesikli proses ile zeytin yağı üretimi esnasında üç ürün oluşmaktadır: zeytinyağı, katı artık ve atıksu [5, 6]. Zeytin yetiştiren Akdeniz Ülkelerinin yıllık zeytinyağı atıksu üretiminin $7 \times 10^{6}$, dan $30 \times 10^{6} \mathrm{~m}^{3}$ e kadar değiştiği tahmin edilmektedir. Bu büyük fark; hava şartlarından ve zeytin ağaçlarını etkileyebilen hastalıklardan dolayı zeytinlerin yıldan yıla değişmesiyle kısmen açıklanabilir. Ortalama toplam atıksu üretimi $10-12 \times 10^{6} \mathrm{~m}^{3} / \mathrm{y} 1 \mathrm{l}$ dır [7].

$\mathrm{Bu}$ atıksuların arıtımıyla ilgili temel sorunlar: (a) konsantrasyonu ve bileşimi, (b) mevsimsel üretim ve (c) zeytinyağı üretim endüstrilerinin günlük 10 ve $100 \mathrm{~m}^{3}$ arasında atıksu debisine sahip küçük tesisler olması ve geniş alanlar üzerinde yayılmasıdır [8]. Kolaylıkla biyolojik olarak ayrışamayan organik kimyasallar ve uçucu yağ asitlerini içeren zeytinyağı atıksularının arıtımı Akdeniz ülkelerinde en önemli çevresel problemlerden biridir. Ayrıca atıksu, arıtılması çok zor olan fitotoksik maddeler ve çeşitli fenol ve polifenol bileşiklerini de içermektedir. Diğer taraftan zeytinyağı üretim tesisleri küçük ve yayılmış durumdadır. Bunların işletme mevsimleri iklime bağlıdır. Bu nedenle atıksuların merkezileşmiş arıtımı mümkün olmamaktadır. Bu, küçük tesislerde zeytinyağı atıksuları arıtımını basit, ucuz ve etkili kılan bir çözümün bulunması gerektiği anlamına gelmektedir. Şu anda böyle ekonomik ve basit bir çözüm henüz mevcut değildir [9]. Daha sıkı olan çevre yasaları ve uygulamalarından dolayı zeytinyağı atıksularının arıtımı için farklı metotlar önerilmiştir. Ancak şimdiye kadar esneklik, verim, pratiklik ve maliyet analizleri açısından bu metotların çoğunun yetersiz olduğu görülmüştür [10].

Aşırı derecede yüksek organik madde ve dirençli madde içerikli arıtılmamış zeytinyağı atıksularının kanalizasyona deşarjından dolayı Türkiye'de pek çok merkezi kentsel atıksu arıtma 
tesislerinin zeytin kampanyası döneminde kapatılması gerekmiştir [11]. Türkiye'de Su Kirliliği Kontrolü Yönetmeliği, kentsel atıksu arıtma tesisiyle sonlanan kanalizasyon kanallarına 4000 mg/L'e kadar kimyasal oksijen ihtiyacına (KOİ) sahip atıksuların deşarjına izin vermektedir. Zeytinyağı atıksuları için alıcı su ortam deşarj standartları ise Tablo 2'de verilmiştir [12].

Tablo 2. Gıda Sanayi (Zeytinyağı ve Sabun Üretimi, Katı Yağ Rafinasyonu) Atıksularının Alıcı Ortam Deşarj Standartları [12].

\begin{tabular}{lll}
\hline Parametre & Kompozit Numune 2 saatlik & Kompozit Numune 24 saatlik \\
KOİ (mg/L) & 250 & 230 \\
Yağ ve Gres (mg/L) & 60 & 40 \\
$\mathrm{pH}$ & $6-9$ & $6-9$ \\
\hline
\end{tabular}

$\mathrm{Bu}$ araştırmada zeytinyă̆ üretim atıksularının arıtımı üzerine yapılan çalışmalar incelenmiştir. Literatür 1şı̆̆ında zeytinyağı üretim prosesleri ve üretim sonrasında oluşan atıksuların bileşimi sunulmuştur. Atıksu arıtımında kullanılan yöntemlerin mekanizması, avantaj ve sınırlamaları özetlenmiştir.

\section{Zeytinyağı Üretim Prosesleri}

Zeytinyağı üretiminde kullanılan temel metotlar, kesikli (klasik pres prosesi) ve sürekli üretim (santrifüj proses) prosesleridir.

\subsection{Klasik Pres Prosesi (Kesikli Üretim Prosesi )}

Bu üretim sistemi besleme, hammadde depolama, temizleme, kabuk kırma ve ezme, kurutmakavurma, sıkma, filtrasyon/dekantasyon ünitelerinden oluşmaktadır [13]. Zeytinler yıkanmakta, ezilerek öğütülmekte ve sıcak su ilavesiyle yoğrulmaktadır. Oluşan hamur daha sonra yağını süzmek için preslenmektedir. Preslerden açığa çıkan sıvı atık, zeytin suyu ve ilave edilen su karışımından oluşmakta ve arta kalanı yăg içermektedir. Son olarak zeytinyağı düşey santrifüj veya dekantörler ile sudan ayrılmaktadır. Katı faz ise pirina olarak elde edilmektedir. Pres teknolojisi az su gerektirmekte, fakat yüksek derecede kirli atıksu üretmektedir. Bugün zeytinyağı üretiminin önemli kısmı hala pres teknolojisi ile sağlanmaktadır [3].

\subsection{Santrifüj Prosesi (Sürekli Üretim Prosesi)}

Bu üretim sistemi; besleme, yıkama, kırma ve hamur hazırlama ünitelerinden oluşmaktadır [13]. Sürekli işletmede kullanılan ayırma metoduna bağlı olarak iki teknoloji tanımlanmaktadır: İki fazlı ve üç fazlı prosesler. Üç fazlı proseslerde su ilave edilmekte ve üç faz (yăg, atıksu ve katı atık) üretilmektedir. Ancak iki fazlı proses, 2 faz (yağ ve su-katı karışımı) içermektedir. İki fazlı proseste, üç fazlı prosesten çok daha az su kullanılmaktadır. Şekil 1'de zeytinyağı üretim prosesleri özetlenmiştir [3]. Farklı basamaklar sırasında üç fazlı ve iki fazlı zeytinyağı ekstraksiyon proseslerinde üretilen atıksuların ortalama hacimleri Tablo 3'de görülmektedir.

Zeytinyağı ekstraksiyonu için üç fazlı sürekli santrifüj, işleme kapasitesini ve ekstraksiyon verimini arttırmak ve iş gücünü azaltmak için 1970’lerde getirilmiştir. Sonuç olarak üç fazlı santrifüj proses; ortalama işletme büyüklüğünde artışa, işletmelerin toplam sayısında azalmaya, artan su tüketimine ve atıksuların artışına yol açmıştır [7]. 
Klasik proses teknolojisine göre sürekli santrifüjün temel avantajları; artan üretim, azalan iş gücü maliyeti, daha az yer ihtiyacı, daha iyi kalite, gelişmiş proses kontrolü ve otomasyonda kolaylıktır. Pres teknolojisi ile karşılaştırıldığında yüksek yatırım maliyetine sahiptir.

Sürekli proseslerde elde edilen katı fazlar su bakımından oldukça zengindir. Üç fazlı sistemde \%30-50, iki fazlı sistemde \%60-70’tir. Atıklar \%2-4 kalıntı zeytinyağı içermektedir. Pres proseste ürünün tonu başına 0.4-0.6 $\mathrm{m}^{3}$ atıksu üretilirken, 3 fazlı proseste $1.0-1.2 \mathrm{~m}^{3}$ atıksu üretilmektedir. Fakat pres sistem, üç fazlı sistemle karşılaştırıldığında kirleticiler bakımından daha konsantre atıksu oluşturmaktadır. İki fazlı proseste atıksu miktar olarak daha azdır ve temel olarak yıkama suyundan ortaya çıkmaktadır. İki fazlı sistem proses suyundan \%80’e kadar tasarruf sağlamaktadır. Üç fazlı sistemle karşılaştırıldığında $\% 25$ kadar daha az yatırım maliyeti gerektirmektedir [3].
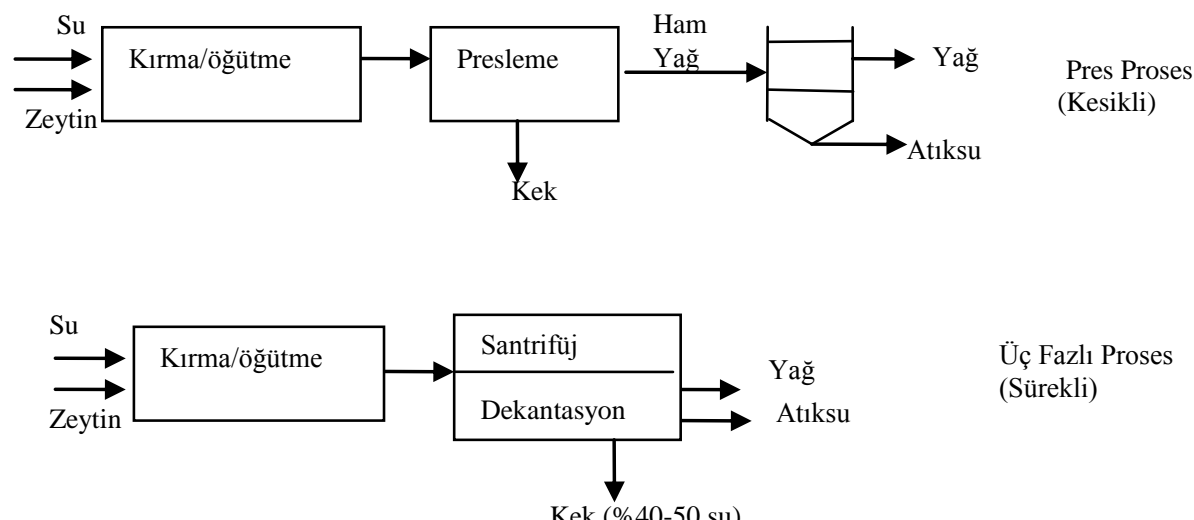

Üç Fazlı Proses (Sürekli)

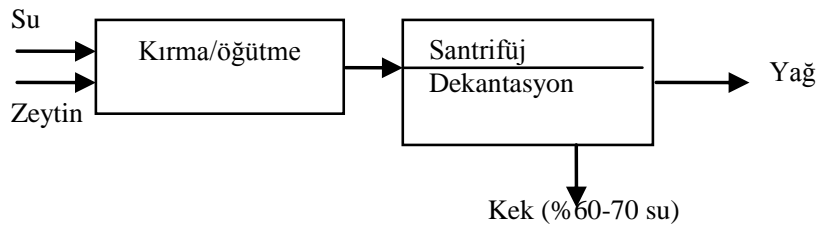

İki fazlı Proses (Sürekli)

Şekil 1. Zeytinyağı üretiminde kullanılan proseslerin akım şeması [3].

Tablo 3. Üç fazlı ve iki fazlı zeytinyağı ekstraksiyon proseslerinin farklı basamaklarında üretilen atıksuların ortalama hacimleri [7]

\begin{tabular}{lll}
\hline Çıkış Suyu & Üç Fazlı Proses & İki Fazlı Proses \\
& (L/kg işlenilen zeytin) & (L/kg işlenilen zeytin) \\
Zeytinleri yıkama & 0.09 & 0.05 \\
Yatay santrifüj & 0.9 & 0.00 \\
Zeytinyağı yıkama (Düşey santrifüj) & 0.2 & 0.15 \\
Genel temizleme & 0.05 & 0.05 \\
Toplam çıkış suyu & 1.24 & 0.25 \\
\hline
\end{tabular}

\section{Zeytinyağı Üretim Atıksularının Özellikleri}

Zeytinyağı atıksularının miktarı ve özellikleri; zeytin çeşidi, yetiştirme sistemi, meyvenin olgunluk derecesi, iklim şartları, tarım toprağı, hasat etme zamanı, pestisit ve gübre kullanımı, yaşlanma süresi ve yağ ekstraksiyon işlemi gibi pek çok faktöre bağlı olarak değişmektedir [1, 7, 14-17]. Santrifüj ekstraksiyon sistemleriyle karşılaştırıldığında, klasik pres ekstraksiyon metodu ile sıvı atık üretimi daha 
düşüktür. Klasik birimlerden açığa çıkan atıksular modern birimlerden açığa çıkan atıksulardan organik madde bakımından daha konsantredir [18].

Zeytinyağı üretim atıksuları, su (\%83-92), organik madde (\%4-16) ve mineral tuzlardan (\%1-2) oluşan kötü kokulu asidik atıksulardır. Organik madde; şekerler, azotlu bileşikler, yağ asitleri, polialkoller, polifenoller, pektin ve yağlardan oluşmaktadır [19]. Üç fazlı zeytinyağı üretim atıksuları; spesifik keskin zeytinyağı kokusu, yüksek derecede organik kirlilik (220 g/L’e kadar KOİ değeri), 3 ve 6 arasında pH (biraz asidik), yüksek elektriksel iletkenlik, yüksek polifenolik içerik (0.5-24 g/L) ve yüksek katı madde içeriği ile karakterize edilmektedir. Bu atıksular; fruktoz, monos, glukoz, sakkaroz, sukroz ve biraz pentozdan ibaret olan \%1.6-4 şeker içermektedir. Tablo 4'de zeytinyağı atıksularının temel kirlilik parametrelerinin maksimum ve minimum değerleri özetlenmiştir [7]. Bu atıksuların rengi, degradasyon durumuna ve hakim olan iklime bağlı olarak koyu kırmızıdan siyaha kadar değişmektedir [20]. Zeytinyağı atıksuları; 89-100 g/L aralığında biyokimyasal oksijen ihtiyacı (BOİ) ve 80-200 g/L aralığında KOİ değerlerine sahip yüksek kirlilik gücüne sahiptirler [21, 22]. Bu değerler, tipik kentsel atıksuların değerlerinden yaklaşık 200-400 kat daha yüksektir [21-24].

Zeytinyağı atıksuları düşük moleküler ağırlıklı fenol bileşiklerinden kompleks yüksek moleküler ağırlıklı bileşiklere kadar farklı moleküler ağırlık aralığında çeşitli fenolik bileşikleri içermektedir [25]. Zeytinyağı atıksularında bulunan fenolik bileşikler; (1) koumarik, kafeik ve ferulik asit gibi sinnamik asit türevleri, (2)vanilik, gallik, veratrik, protokateşik ve hidroksibenzoik asitler gibi benzoik asit türevleri ve (3) tirosol ve hidroksitrisol ve hidroksifenilasetik asit gibi ilgili bileşikler olmak üzere üç temel kategoride sınıflandırılabilir [8]. Fenolik kısım, zeytinyağı atıksuları ile ilgili olan problemlerin çoğundan sorumludur. Birincisi aşırı derecede renkli olmasıdır. İşlenen zeytinlerin yaşına ve tipine bağlı olarak koyu kırmızıdan siyah renge kadar değişmektedir. Atıksuya rengi, yüksek moleküler ağırlıklı fenolik bileşikler vermektedir. 1/1000 seyreltmeden sonra bile sudaki renk hala gözle görülebilir şekilde fark edilmektedir [26]. Zeytinyağı atıksularında yüksek konsantrasyonlarda bulunan fenolik bileşikler, fitotoksisite ve antimikrobiyal özelliklere sahip olan ve biyolojik olarak ayrışması zor olan kalıcı bileşiklerdir [22]. Bununla birlikte, düşük pH ve polifenollerin kompleks oluşturma yetenekleri çevredeki ağır metallerin çözünürlüğünü arttırmaktadır [27].

Tablo 4. Zeytinyağı atıksuları temel kirlilik parametrelerinin maksimum ve minimum değerleri [7].

\begin{tabular}{lll}
\hline Parametre & Maksimum & Minimum \\
\hline $\mathrm{pH}$ & 6.7 & 4.0 \\
Redoks potansiyeli, mV & -330 & -80 \\
İletkenlik, mS/cm & 16 & 8 \\
Yoğunluk, g/L & 1.100 & 1.016 \\
Bulanıklık, birim & 62000 & 42000 \\
Askıda katı madde, g/L & 9 & 1 \\
Çökelebilen katı madde, mL/L.saat & 250 & 10 \\
BOİ, mg/L & 110000 & 35000 \\
KOİ, mg/L & 170000 & 45000 \\
Oksijen alım hızı, mg/L.saat & 100 & 50 \\
Toplam bakteri, 10 ${ }^{6}$ koloni/mL & 5 & - \\
\hline
\end{tabular}


$\mathrm{Bu}$ atıksular, toprak verimliliğinde önemli faktörler olan azot, fosfor, kalsiyum, magnezyum ve demirin dikkate değer seviyelerine ve yüksek potasyum konsantrasyonuna da sahiptir [28]. Üç fazlı zeytinyağı atıksularında $\mathrm{g} / \mathrm{L}$ olarak $\mathrm{K}^{+}(9.80), \quad \mathrm{Mg}^{2+}(1.65), \quad \mathrm{Ca}^{2+}(1.35), \quad \mathrm{Na}^{+}(0.162), \quad \mathrm{Fe}^{2+}(0.033)$, $\mathrm{Zn}^{2+}(0.0301), \mathrm{Mn}^{2+}(0.0091)$, ve $\mathrm{Cu}^{2+}(0.0098)$ katyon ve $\mathrm{CI}^{-}(1.3), \mathrm{H}_{2} \mathrm{PO}_{4}^{-}(0.85), \mathrm{F}^{-}(0.53), \mathrm{SO}_{4}{ }^{2-}(0.42)$, $\mathrm{NO}_{3}^{-}(0.0109)$ anyon konsantrasyonları bulunmuştur [7].

Zeytinyağı atıksuları, fazla sayıda bakteriler, mayalar ve mantarları da içermektedir. Teşhis edilen soylar arasında, Acinetobacter, Pseodomonas ve Enterobacter'in çeşitli türleri bulunmuştur. Mantar cinsleri arasında, 12 farklı tür (Acremonium, Alternaria, Aspergillus, Chalara, Fusarium, Lecytophora, Paecilomyces, Penicillium, Phoma, Phycomyces, Rhinocladiella ve Scopulariopsis) bulunmuştur [7].

İki fazlı zeytinyağı üretim katı atı̆̆ının ortalama bileşimi; su (\%60-70), lignin (\%13-15), selüloz ve hemiselüloz (\%18-20), hamurda tutulan zeytinyağı (\%2.5-3) ve mineral katılardır (\%2.5). Organik bileşenler arasındaki temel bileşenler; şekerler (\%3), uçucu yağ asitleri (\%1), polialkoller (\%0.2), proteinler (\%1.5), polifenoller (\%0.2) ve başka pigmentlerdir (\%0.5) [29]. Üç fazlı ve iki fazlı zeytinyağı ekstraksiyon proseslerinin farklı kademelerinde üretilen atıksuların bileşimi ve özellikleri Tablo 5'de özetlenmiştir.

Tablo 5. Üç fazlı ve iki fazlı zeytinyağı ekstraksiyon proseslerinin farklı kademelerinde üretilen atıksuların bileşimi ve özellikleri

[7].

\begin{tabular}{|c|c|c|c|c|c|c|}
\hline \multirow[t]{2}{*}{ Çıkış Suyu } & \multicolumn{3}{|c|}{ Üç Fazlı Proses } & \multicolumn{3}{|c|}{ İki Fazlı Proses } \\
\hline & $\begin{array}{l}\text { Katılar } \\
(\%)\end{array}$ & $\begin{array}{l}\text { Yăg } \\
(\%)\end{array}$ & $\begin{array}{l}\text { KOÍ } \\
(\mathrm{g} / \mathrm{kg})\end{array}$ & $\begin{array}{l}\text { Katılar } \\
(\%)\end{array}$ & $\begin{array}{l}\text { Yăg } \\
(\%)\end{array}$ & $\begin{array}{l}\text { KOÍ } \\
(\mathrm{g} / \mathrm{kg})\end{array}$ \\
\hline Zeytinleri yıkama & 0.51 & 0.14 & 7.87 & 0.54 & 0.1 & 0.87 \\
\hline Yatay santrifüj & 6.24 & 0.96 & 73.82 & 0 & 0 & 0 \\
\hline $\begin{array}{l}\text { Zeytinyağı yıkama } \\
\text { (Düşey santrifüj) }\end{array}$ & 0 & 0 & 0 & 1.42 & 0.57 & 1.17 \\
\hline Son çıkış suyu & 4.86 & 0.31 & 68.61 & 2.82 & 0.29 & 2.25 \\
\hline
\end{tabular}

\section{Zeytinyağı Atıksularının Çevresel Etkileri}

Bu atıksuların en önemli çevresel etkileri aşağıdaki şekilde verilebilir.

1) Sucul yaşamı tehdit etme. Zeytinyağı üretim atıksuları kentsel atıksulardan 100 kat daha yüksek organik madde içermektedir. Alıcı su ortamına deşarj edildiğinde oksijen mevcudiyeti azalmakta, tüm ekosistemin dengesi bozulmaktadır. Atıksuda bulunan nutrient alg gelişimini desteklemekte ve sonuç olarak ötrofikasyonu artırmaktadır.

2) Koku problemi. Bu atıksular açık havuzlarda depolandığında ve/veya araziye veya doğal sulara deşarj edildiğinde fermantasyon olayı yer almaktadır. Sonuç olarak metan ve diğer keskin gazlar (hidrojen sülfür, vb.) yayılmaktadır. Bu, yağ üretim periyodu süresince büyük mesafalerde bile koku olarak önemli kirliliğe yol açmaktadır.

3) Geçirimsiz film. Bu atıksulardaki lipitler, alıcı sulardaki mikroorganizmaların güneş ışığı ve oksijeni almasını engelleyen geçirimsiz bir film tabakasını su yüzeyinde oluşturmaktadır.

4) Doğal suların renklenmesi. Doğal suların rengindeki değişim oksidasyona ve taninlerin polimerizasyonuna bağlanılabilir. 
5) Toksisite. Zeytinyağı üretim atıksuları çeşitli fitotoksik uçucu asitler ve fenolik bileşiklerin varlığından dolayı çok toksiktir [30].

\section{Zeytinyağı Üretim Atıksularını Arıtma Teknolojileri}

\subsection{Biyolojik Prosesler}

Atıksu arıtımında biyolojik prosesler dünya çapında kabul görmektedir. Biyolojik proseslerin çevre dostu, güvenilir ve genellikle uygun maliyetli olduğu düşünülmektedir. Biyolojik arıtma, organik madde ve inorganik nutrientleri giderebilmektedir. Fenolik maddeler mikroorganizmalara toksik olduğu için, kullanılan mikroorganizmaların seçimi ve arıtılan zeytinyağı atıksularına adaptasyonu dikkate alınmalıdır [1]. Biyolojik prosesler (aerobik veya anaerobik) fenolik bileşiklerin inhihisyon etkisinden dolayı genellikle uzun sürmekte ve organik kirlilik yükünü tamamen giderememektedir. Ayrıca biyogaz üretiminin ekonomik olmadığı ve meydana gelen kalıntının yönetimi ve depolanmayan biyogazın kullanımı gibi ek problemlere sebep olduğu ispatlanmıştır [31].

\subsubsection{Anaerobik Çürütme}

Anaerobik çürütme, aerobik mikroorganizmalardan daha düşük büyüme hızına sahip olan anaerobik mikroorganizmalar tarafından moleküler oksijen yokluğunda yürütülmektedir [1]. Metanojenik şartlar altında organik maddenin anaerobik çürütmesi dört kademeye ayrılabilen kompleks bir prosestir. İlk kademede bipolimerler basit şekerler, aminoasitler, uzun zincirli yağ asitleri ve aromatik bileşikler gibi monomerlere hidrolizlenmektedir. İkinci kademede, asidojenik bakteriler bu monomerleri uçucu yağ asitleri ve alkoller gibi ara organik bileşikler ile $\mathrm{CO}_{2}$ ve $\mathrm{H}_{2}$ 'nin eş zamanlı üretimine fermente etmektedirler. Üçüncü kademede asetogenesis, asetojenik bakteriler bu ara organik ürünleri metabolize etmekte, metanojenik substratlar, asetat ve hidrojen oluşmaktadır. Son kademede metanojenik bakteriler tarafından metan ve $\mathrm{CO}_{2}$ 'e dönüştürülmektedir [32].

Zeytinyağı atıksularının anaerobik arıtımındaki zorluklar temel olarak, yüksek organik konsantrasyon, mevsimsel işletme, geniş alanda dağılma ve biyolojik olarak kalıcı ve/veya inhibe edici maddelerin varlığıyla ilişkilidir [25].

Aerobik arıtma ile karşılaştırıldığında pek çok avantaja sahip olduğu için, anaerobik ayrıştırma zeytinyağı atıksuları arıtımı için genellikle temel biyolojik prosestir. Anaerobik ayrıştırma ile yüksek organik yüklü beslemelerde oldukça yüksek derecede arıtma sağlanabilmekte, düşük nütrient ihtiyaçları gerekmekte, genellikle düşük miktarda atık çamur (aerobik arıtmadan 20 kat az) ve yanabilen bir biyogaz üretilmektedir. Fiziksel, fizikokimyasal veya biyolojik aerobik arıtmalar gibi diğer proseslerle karşılaştırıldığında biyogaz üretimi işletme maliyetlerini azaltabilmektedir [7]. Birkaç ay kapatmadan sonra bile anaerobik çürütücüler kolaylıkla yeniden işletmeye alınabildiği için sezonluk zeytinyağı üretim atıksularının üstesinden gelebilmektedir [8].

Anaerobik arıtma avantajlara sahip, fakat genellikle fazlaca uzun sürmektedir. Ayrıca fenolik bileşikler ve mineral tuzların varlığından kaynaklanan yüksek toksisite ve biyoayrışma inhibisyonundan dolayı pek çok problem yaşanmaktadır [10]. Bu durum anaerobik arıtmadan önce mümkün olduğu kadar daha seçici bir şekilde lipitleri ve fenolik bileşikleri gidermek için fiziksel-kimyasal ön arıtma seçeneğinin yürütülmesi gerektiğine işaret etmektedir [25]. 
Zeytinyağı atıksuları KOİ bakımından kuvvetli, fakat azot bakımından yetersizdir. Pres ve santrifüj sistemlerinde açığa çıkan atıksuların C:N:P oranları sırasıyla 100:1.77:0.94 ve 100:1.34:0.70'dir. Düşük $\mathrm{pH}$ ve depolama esnasında uçucu yağ asitlerinin oluşumundan kaynaklanan inhibitör etkiler anaerobik çürütmede problemler yaratabilmektedir. Bu olumsuz etkilerine rağmen, zeytinyağı üretim atıksuları ön arıtma ve bileşiminin ayarlanmasından sonra anaerobik arıtma için uygun olmaktadır [3].

Zeytinyağı atıksularının arıtımında pek çok anaerobik proses kullanılabilmektedir. Anaerobik lagünleme, anaerobik kontakt prosesi, yukarı akışlı anaerobik çamur yataklı reaktör, anaerobik filtreler bu prosesler arasında yer almaktadır. Anaerobik lagünleme ile ulaşılan verim \%20-30 ile \%75-80 arasında değişirken zeytinyağı atıksularının alıkonma süresi 2-4 ay olmaktadır. Yukarı akışlı anaerobik çamur yataklı reaktörler, zeytinyağı atıksularından çok daha düşük kirlilik konsantrasyonlarına sahip atıksuların arıtımı için kullanılmaktadır. Bu nedenle bu reaktörlerde zeytinyağı atıksularının arıtımı için yüksek oranlarda seyreltilmesi gerekmektedir. Anaerobik filtreler doğal veya sentetik dolgu malzemesinin bulunduğu, bu malzeme üzerinde bakterilerin sabit biyofilm formunda büyüdüğü bir ortamdır. Bu filtrelerin en önemli avantajı, proses kontrolünün kolay olması ve değişken yükleme değerlerinin sorun yaratmamasıdır [33].

Anaerobik filtre veya yukarı akışlı anaerobik çamur yataklı reaktör gibi yüksek hızlı anaerobik prosesler 10-20 g/L KOİ içeren zeytinyağı atıksularını arıtmak için kullanılabilir. Klasik anaerobik kontakt reaktörler $60 \mathrm{~g} / \mathrm{L}$ 'e kadar yüksek KOİ konsantrasyonlarında kullanılarak \%80'den fazla KOİ giderim verimi elde edilmektedir. Ancak anaerobik prosesler, zeytinyağı atıksularının arıtımında kullanılırsa ön arıtma gereklidir [3].

Aggelis vd. [32], anaerobik proses ile yeşil zeytin atıksularının potansiyel biyolojik arıtımını araştırmışlardır. Anaerobik çürütme ile maksimum $\% 49$ organik madde giderimi ve $\% 12$ polifenolik madde giderimi elde etmişlerdir. Polifenolik bileşikler anaerobik populasyonu özellikle metanojenik bakterileri inhibe etmiş̧ir. Ergüder vd. [34], biyokimyasal metan potansiyel testleri ile farklı başlangıç kimyasal oksijen ihtiyacı konsantrasyonlarında zeytinyağı atıksuların anaerobik biyoayrışabilirliğini araştırmışlardır. Atıksular anaerobik olarak \%85.4-93.4 gibi yüksek bir verimle arıtılmıştır. Anaerobik

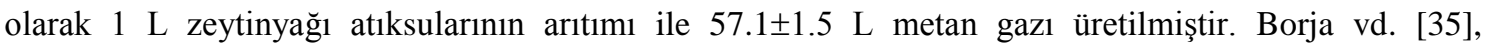
laboratuar ölçekli anaerobik hibrid reaktör kullanarak $8 \mathrm{~kg} \mathrm{KOI} / \mathrm{m}^{3}$.gün organik yüklemede zeytinyağ atıksularından \%89'den daha fazla KOİ giderimi elde etmişlerdir.

\subsubsection{Aerobik Aritma}

Aerobik arıtma atıksu arıtımında yaygın şekilde kullanılan bir teknolojidir. Aerobik mikroorganizmaların oksijen varlığında kirlilikleri okside ederek parçalaması esasına dayanır. Organizmalar kirlilikleri kullanarak çamur gibi yeni hücreler üretirler. Arıtım sonrasında çok yüksek miktarlarda çamur oluşmaktadır. Genellikle atıksuda düşük konsantrasyonlarda bulunan çözünmüş ve kolloidal haldeki kirlilikleri arıtırlar. Yüksek konsantrasyonlardaki kirlilikler ise ancak yüksek alıkonma sürelerinde ve yüksek geri devir oranlarında arıtılabilir. Bu nedenle, zeytinyağı atıksularının aerobik biyolojik arıtımı, çok yüksek KOİ ve fenol içeriği nedeniyle uygun değildir. Zeytinyağı atıksularına mikroorganizmaların adaptasyonu için alıştırma periyoduna ihtiyaç duyulmaktadır [33].

Aggelis vd. [32], aerobik mikroorganizmalar ile yeşil zeytin atıksuların degradasyonunu araştırmışlardır. 10 günlük hidrolik bekleme süresinde \%71.6-75.9 degradasyon verimi elde etmişlerdir. 
Prosesin dezavantajları giriş suyu $\mathrm{pH}$ ayarlaması ve yüksek biyokütle üretimidir. Benitez vd. [36], mikroorganizma adaptasyonundan sonra tam karışımlı kesikli aktif çamur reaktöründe zeytinyağ atıksularının aerobik ayrışmasını incelemişlerdir. $22 \mathrm{~g} / \mathrm{L}$ başlangıç KOİ değerinde \%81-84 ve 65-98 g/L başlangıç KOİ değerlerinde \%58-68 aralığında KOİ giderimi elde etmişlerdir. \%90 fenol giderimi sağlamışlardır.

\subsubsection{Biyolojik Ön Arıtma}

Aerobik ön arıtma zeytinyağı atıksularındaki kirleticilerin bir kısmını ayrıştırabilmekte ve en önemli olarak fenollerin miktarını azaltarak atıksuyun toksisitesini azaltabilmektedir. Böylece atıksu sonraki arıtma için daha uygun hale gelmektedir [1].

Antimikrobiyal etkilerinden dolayı fenolik bileşikler hem aerobik hem de anaerobik prosesler ile zeytinyağı atıksuların degradasyonu için sakıncalıdır. Pek çok araştırma zeytinyağı atıksuların başlangıç organik yükünü ve fenolik içeriğini azaltmak amacıyla seyreltilmiş zeytinyağı atıksularında aerobik olarak büyüme yeteneğine sahip olan mikroorganizmalar kullanılarak yürütülmüştür.

Geotrichum sp., Aspergillus sp., ve Candida tropicalis kültürlerini kullanarak zeytinyağı atıksularından polifenol biyodegradasyonunu araştıran Fadil vd. [21], Geotrichum sp., , Aspergillus sp. ve $C$. tropicalis ile sırasıyla $\% 55, \% 52.5$ ve $\% 62.8$ KOİ giderimi sağlamışlardır. Polifenol giderimini ise \%46.6 (Geotrichum sp.), \%44.3 (Aspergillus sp.) ve \%51.7 (C. Tropicalis) olarak elde etmişlerdir. Fountoulakis vd. [37], Pleurotus ostreatus ile zeytinyağı atıksularından fenolik maddelerin giderimi ve anaerobik çürütme performansı üzerinde zeytinyağı atıksuların ön arıtımının etkisini araştırmışlardır. Termal olarak işlenmiş ve seyreltilmemiş zeytinyağı atıksularından $\% 64.7$ fenol giderdiği ve metanojenik bakterilere karşı inhibisyonu yeterince azaltarak ardışık anaerobik ayrışma performansını arttırdığı bulunmuştur.

Lamia ve Moktar [38], zeytin fabrikası atıksularından fenolik bileşiklerin biyodegradasyonu ve renk giderimi üzerinde Lactobacillus plantarum'un etkisini incelemişlerdir. Atıksu 10 kat seyreltildiğinde renk $\% 58$, KOİ $\% 55$ ve fenolik bileşikler $\% 46$ giderilmiştir. González-González ve Cuadras [39], ön arıtımsız zeytin fabrikası atıksularını anaerobik çürütmede kullandıkları çalışmada inhibisyonla karşılaşmışlardır. Fenolik bileşiklerin konsantrasyonunu ve toplam KOI'’i azaltmak için aerobik ön arııı kullanarak 7 günlük havalandırma süresi ile $\% 90$ polifenol ve $\% 21$ toplam KOİ giderimi elde etmişlerdir.

Ön arıtıma sahip anaerobik ayrışma hızının, ön arıtımsız anaerobik ayrışma hızından yaklaşık olarak 2.5-4.5 kat daha büyük olduğu bulunmuştur. Böylece ön arıtma sonraki anaerobik arıtmanın giderim hızlarını artırabilmektedir [1].

\subsubsection{Birleşik Biyolojik Prosesler}

Maksimum giderim verimleri sağlandığında bile, anaerobik veya aerobik prosesler tek başına arıtma gereksinimleri için yeterli olmamaktadır. Bu nedenle birleşik sistemler de çalışılmıştır.

Aggelis vd. [32], yeşil zeytin atıksularını birleşik anaerobik-aerobik proses ile arıtımını araştırmışlardır. Anaerobik ve aerobik kademede sırasıyla 50 gün ve 5 gün hidrolik bekleme süresine sahip olan böyle iki kademeli bir proses ile $\% 83.5$ toplam KOİ giderimi ve $\% 28$ polifenol giderimi elde edilmiştir. Zeytinyağı atıksularının organik yükünü önemli derecede azaltmak için birleşik anaerobikaerobik biyoarıtım etkili bir arıtma olarak önerilmektedir. Polifenol giderimi için ön arıtma kademesinin 
kullanımı anaerobik kademenin verimini arttırmaktadır. Birleşik anaerobik-aerobik arıtma daha düşük miktarda aerobik çamur üretmektedir. Anaerobik veya aerobik giriş suyu pH ayarlamasına ihtiyaç duymaz.

Dalis vd. [40], seri şekilde işletilen iki anaerobik reaktör birleşik sisteminde zeytinyağ atıksuların arıtımını incelemişlerdir. İlk reaktör yukarı akışı anaerobik reaktör ve ikinci reaktör sabit yataklı reaktör olarak işletilmiştir. Birinci reaktörde KOİ giderimi $11 \mathrm{~g} \mathrm{KOİ/L.gün} \mathrm{organik} \mathrm{yükleme}$ hızında $\% 83$ ve ikinci reaktörde $0.19 \mathrm{~g} \mathrm{KOİ/L.gün} \mathrm{organik} \mathrm{yükleme} \mathrm{hızında} \mathrm{KOİ} \mathrm{olarak} \mathrm{ilave} \% 8$ giderim sağlanmıştır. Fenol, birinci reaktörde $\% 75$ ve ikinci reaktörde ilave $\% 45$ giderilmiştir.

\subsubsection{Başka Atıksular ile Birlikte Arıtma}

Başka çıkış suları ile beraber zeytinyağı atıksularını karıştırma ve ayrıştırma besleme suyunun KOİ ve toplam fenol konsantrasyonunu azaltma, eğer zeytinyağı atıksuları nütrientler bakımından zengin çıkış suları ile karıştırılırsa nütrient (mesela azot ve fosfor) ilavesine gerek olmaması ve mevsimsel olarak üretilen çıkış sularını birlikte ayrıştırmaya dayanan arıtma tesislerinin bütün yıl boyunca çalışma imkanı gibi pek çok avantaj sunmaktadır [8]. Ayrıca ihtiyaç duyulan $\mathrm{pH}$ ve alkalinite seviyelerini sağlama avantajına da sahiptir. Bu şekilde birlikte arıtmanın her bir çıkış suyunu ayrı olarak arıtmadan daha ekonomik olması da beklenmektedir [1].

Marques [41], aynı olan iki tane yukarı akışlı anaerobik filtrede domuz ahırı atıksuları (ham ve anaerobik olarak çürütülmüş) ile zeytinyağı atıksularını birlikte arıtarak KOİ giderimi bakımından karşılaştırmıştır. Ham domuz ahırı atıksuları ile birlikte arıtma 3.1-5.7 kg KOI $/ \mathrm{m}^{3}$.gün organik yükleme hızlarında \%76 KOİ giderimi sergilemiştir. Daha yüksek organik yükleme hızı KOİ giderimini azaltmıştır. Çürümüş domuz ahırı atıksuları ile birlikte arıtımda $3.1-10 \mathrm{~kg} \mathrm{KOİ} / \mathrm{m}^{3}$.gün organik yükleme hızlarında \%70'den daha yüksek KOİ giderimi elde edilmiştir. Her iki şemada hidrolik bekleme süresi yaklaşık 6-7 gündür ve optimal seyreltme $\% 83$ (v/v) zeytinyağı atıksularıdır. Fenol giderimine gelince, ham domuz ahırı çıkış suları ile birlikte arıtma çürümüş domuz ahırı çıkış suları ile birlikte arıtmadan daha büyük verim (sırasıyla \%63 ve \%53) göstermiştir.

Gizgis vd. [42], kentsel atıksular ile zeytinyağı atıksularının birleşik anaerobik/aerobik arıtım verimini araştırmışlardır. Yukarı akışlı anaerobik çamur yataklı reaktör zeytinyağı atıksuların ve ön çökeltme havuzunun kentsel atıksularının karışımı ile beslenilmiştir. Zeytinyağı atıksuları/kentsel atıksu hacmi oranı 1:17 ve 1:33 arasında değiştirilmiştir. 1800 ve $4400 \mathrm{mg} / \mathrm{L}$ arasında değişen giriş KOİ konsantrasyonu anaerobik reaktörde arıtım ile reaktör çıkış KOİ'si 400 ve 600 mg/L'e kadar düşmüştür. Anaerobik reaktörün çıkış suyu küçük ölçekli aktif çamur sisteminde arıtılmıştır. İki basamaklı biyolojik arıtmadan (anaerobik+aerobik) sonra çıkış KOİ seviyesi 85 ve $175 \mathrm{mg} / \mathrm{L}$ arasında değişmiştir. Nihai çıkış suyu düşük seviyelerde askıda katı madde ( 12 ve $42 \mathrm{mg} / \mathrm{L}$ arasında) ve BOİ ( $20 \mathrm{mg} / \mathrm{L}$ ) içermiştir.

\subsubsection{Kompostlama}

Zeytinyağı atıksuları organik gübre olarak doğrudan kullanıldığında bitkiler ve toprak özellikleri üzerinde olumsuz etkiler göstermektedir. Stabil ve kolaylıkla yönetilebilen son ürün üretmek için bu atıkların arıtılması gereklidir. Kompostlama, organik atıkların arıtımı için yaygın şekilde kullanılan bir arıtmadır. Zeytinyağı atıksularını bertaraf etmek için zeytinyağı atıksularını kompostlama ekonomik ve ekolojik olarak kabul gören bir yöntemdir [28]. Kompostlama birkaç haftalık periyotta organik maddeyi 
gübre veya toprak şartlandırıcısı olarak kullanılabilen granüler humus benzeri ürüne dönüştüren aerobik ayrışma prosesidir [1]. Kompostlama işlemi sırasında $\mathrm{CO}_{2}, \mathrm{H}_{2} \mathrm{O}$, mineraller ve stabilize olmuş organik madde oluşmaktadır. Bu nedenle kompostlama işlemi zeytinyağı atıksularının geri kullanımı için pratik ve ekolojik bir yöntemdir. Bu sayede atıksu ve pirinanın herhangi bir fitotoksik etkisi olmaksızın organik gübre olarak kullanılması sağlanmaktadır [33].

Organik madde tamamen toprak şartlandırıcısına dönüştürüldüğü için zeytinyağı üretimi sonucu açığa çıkan katı kalıntılar ile atıksuları birlikte kompostlama çevresel açıdan yeni ve gelecek vadeden bir metottur [31].

Parades vd. [28], kompostlama için zeytinyağı atıksularının uygunluğunu, bu sıvı atığın pamuk çırçır atığı ve atıksu çamuru karışımına ilavesiyle çalışmışlardır. Toprağa zeytinyağı kompostu uygulaması bitkilere zarar vermemiştir. Hem zeytinyağı atıksuyu bulunan kompost hem de zeytinyağı atıksuyu bulunmayan kompost inorganik gübreye benzer bir bitki verimi üretmiştir. Organik veya mineral gübreler ile yetiştirilen bitkilerde potansiyel olarak toksik ağır metallerin birikimi önemli farklılıklar göstermemiştir. Ayrıca toprağa zeytinyağı atıksuyu bulunan kompost uygulaması toprağın kimyasal ve fizikokimyasal özelliklerini de geliştirmiştir.

\subsection{Fiziksel ve Fizikokimyasal Prosesler}

Seyreltme, buharlaştırma, çökeltme, filtrasyon ve santrifüjleme gibi basit fiziksel prosesler zeytinyağı atıksularını arıtmak için kullanılmaktadır. Seyreltme, organik madde ayrışmasından sorumlu mikroorganizmalara karşı toksisiteyi azaltmak için biyolojik arıtmadan önce çok sık kullanılmaktadır. Tek başına bu proseslerin hiçbiri atıksuyun organik yükünü ve toksisitesini kabul edilebilir sınırlara düşürememektedir [1]. Ultrafiltrasyon, ters osmoz, iyon değiştirme ve çeşitli türde adsorbentler (aktif karbon, turba, uçucu kül ve kömür, odun talaşları, silika jel, mısır koçanı, arpa vb.) üzerine adsorpsiyon gibi fiziksel-kimyasal teknikler atıksulardan renk ve KOİ giderim amacıyla etkili bir şekilde kullanılmaktadır. Bu teknikler kirleticileri sudan katı yüzeyine transfer ettikleri için kirleticileri yok etmemektedirler [11].

\subsubsection{Buharlaștırma}

Buharlaştırma havuz sistemleri, düşük maliyette ve vasıfsız iş gücü ile atıksu arıtımında kullanılacak en basit metotlardan biridir. İklim şartları ve meteorolojik şartlar buharlaştırma havuzlarında atıksu biyodegradasyonunu etkilemektedir. Atıksu depolaması süresince havuzlarda doğal buharlaştırma altında su hacmi azalması, mikrobiyolojik flora ile organik ve inorganik bileşiklerin degradasyonu ve mineralizasyonu, bazı bileşiklerin buharlaşması ve son olarak toprak tabakası boyunca atıksuların sızması gibi farklı prosesler meydana gelmektedir [43].

Pratikte Akdeniz ülkelerinde uygun iklim şartlarından ve ihtiyaç duyulan düşük yatırımdan dolayı en yaygın eliminasyon yöntemi açıkta depolama havuzlarında buharlaştırmadır. Ancak bu metot düşük buharlaşma hızlarına sahip bölgelerde büyük alanlara ihtiyaç duymakta, kötü koku, yüzeysel ve yeraltı sularına sızma ve böcek çoğalması gibi çeşitli problemler oluşturmaktadır [44, 45]. Zeytinyağı atıksularının buharlaşması çamur üretmektedir. Ya tarımda ya da yağ içeriğinden dolayı 1sı kaynağı olarak kullanılabilmesine rağmen buharlaşma havuzlarında üretilen çamurun büyük çoğunluğu düzenli depolama alanlarında uzaklaştırılmaktadır [44]. Kalıntı çamuru kompostlama, toprağın organik madde 
bakımından fakir olduğu zeytinyağı üreten ülkelerde düşünülmesi faydalı bir yaklaşım olacaktır. Depolama havuzlarının inşasında kullanılan toprağın yüksek geçirgenliğe ve heterojenliğe sahip olması ciddi çevresel risk yaratmaktadır. Havuzun altında kullanılan kil tabakası toprağa zeytinyağı atıksularındaki dirençli bileşiklerin sızmasını önlemek için sıkıştııılmış ve geçirimsiz olmalıdır [46].

Geniş alanlara ihtiyaç duyulması ve bu tür alanların her zaman yağ fabrikalarının yakınında bulunmaması nedeniyle, atıksuların lagünlere taşınma sorunu ortaya çıkmıştır. Lagünleme yönteminde KOİ giderme verimi düşük, alan gereksinimi yüksek ve maliyet düşüktür. Akdeniz Ülkelerinin çoğu bu atıksuları buharlaştırma lagünlerine boşaltmaktadır [33].

\subsubsection{Koagülasyon/Flokülasyon}

Koagülasyon, küçük partiküllerin makul bir sürede çözeltiden ayrılacak kadar büyük floklar oluşacak şekilde birbiriyle bağlandığı bir prosestir. Katyonik, noniyonik ve anyonik polielektrolitler ya koagülant yardımcısı ya da flokülantlar olarak tanımlanmaktadır. Koagülant polimerlerin, adsorpsiyon prosesi ve partikül yüzey yükü nötralizasyonu ile negatif olarak yüklü partiküllerin koagülasyonunu arttırdığı tahmin edilmektedir. Çözeltideki polieletrolit konsantrasyonu belli bir limitin üzerinde arttırıldığında, partikülün bütün yüzey yükü pozitif olabilir ve emülsiyon yeniden stabilize olabilir. Koagülant yardımcısı polielektrolitlerin hem partiküllere adsorpsiyonuyla hem de partikül ve elektrolit arasında köprülerin oluşumuyla, süspansiyonları destabilize ettiklerine inanılmaktadır [47].

Kireç, alum, demir(III) klorür, demir sülfat gibi metaller ile koagülasyon su/atıksu arıtımında kapsamlı olarak kullanılmaktadır. Kireç, ucuz ve kolaylıkla elde edilebilmesine rağmen, kireç ile koagülasyon genellikle çeşitli dezavantajlara sahiptir:

1) Çözelti $\mathrm{pH}$ 's1 ve sertliğinin artması,

2) Düşük KOİ giderim kapasitesi (tipik olarak \%20-40 arasında),

3) Hala oldukça fitotoksik ve kolayca uzaklaştırılamayan fazla hacimde çamur üretimine yol açan yüksek dozajlara gereksinim ve

4) Verimi arttırmak için flokülasyon ile birleştirme gereksinimi $[17,48]$.

Kestioğlu vd. [11], kanalizasyon sistemine deşarj için Su Kirliliği Standartlarını sağlayan nihai çıkış suyu üretmek için zeytinyağı atıksuları için alternatif ön arıtma metotlarının verimini araştırmışlardır. Demir (III) klorür ve alum koagulantını kullanmışlardır. Asit krakingten sonra demir(III) klorür arıtımı 3 g/L dozda \%95 KOİ, \%90 fenol ve \%99 askıda katı madde giderimi sağlamıştır. Alum 6 g/L dozda benzer giderimler (KOİ \%94 ve fenol \%91) sağlamıştır. Giriş suyu litresi başına 500-700 mL çamur oluşmuştur.

Meyssami ve Kasaeian [47], doğal katyonik polielektrolit olan Kitosan ve diğer benzer koagülantları zeytinyağı atıksuların arıtımında kullanmışlardır. pH 6'da sırasıyla 15 ve 25 ppm konsantrasyonlarında birlikte kullanılan kitosan ve alüm en düşük bulanıklık değerini sağlamıştır. Temel koagülant olarak alüm ve koagülasyon yardımcısı olarak kitosan bulanıklığı azaltmada çok etkili olmuştur (\%90). Demir (III) klorür ve nişastanın etkili koagülant maddeleri olmadığı belirlenmiştir.

Sarika vd. [48], doğrudan flokülasyon (önce koagülasyon kullanmaksızın) ile zeytinyağ atıksuların ön arıtımını dört katyonik (FO-4700-SII, FO-4490-SII, FO-4350-SHU ve FO-4190) ve iki anyonik (FLOCAN 23 ve AN 934-SH) polielektrolit kullanarak araştırmışlardır. Çalışmada kireç ve demir (III) klorür de kullanmışlardır. Polielektrolitlerin çoğunun çözelti pH'sını değiştirmeksizin toplam 
askıda katı maddeyi tamamen gidermesi yanında önemli ölçüde KOİ ve BOİ giderimini de gerçekleştirdiğini gözlemlemişlerdir (\%55 KOİ ve \%23 BOİ). Kireç ve demir (III) klorür ile koagülasyon, toplam askıda katı madde açısından etkili olmasına rağmen polielektrolitlerden daha düşük organik madde giderimi sağlamıştır. Kireç arıtımı, polielektrolit ile arıtımdan daha yüksek dozaj ve daha uzun arıtma süresi gerektirmekte ve ayrıca çıkış suyu pH’sını önemli ölçüde arttırmaktadır. Katı madde giderimi için kireç ve demir (III) klorür ile arıtım, polielektrolit ile arıtımdan genellikle daha ucuzdur. Papaphilippou vd. [49], zeytin fabrikası atıksularının arıtımında koagulant olarak $\mathrm{FeSO}_{4} .7 \mathrm{H}_{2} \mathrm{O}(6.67 \mathrm{~g} / \mathrm{L})$ ve flokulant olarak FLOCAN $23(0.287 \mathrm{~g} / \mathrm{L})$ kullanarak \%97 toplam askıda katı madde, \%72 KOİ ve $\% 40$ toplam fenol giderimi elde etmişlerdir.

Kimyasal maddelerin ilavesine dayanan koagülasyon ve flokülasyon gibi fizikokimyasal metotlar çözülebilir kirleticileri ve kolloidal partikülleri katı bir atı̆̆a dönüştürmektedir [20]. Bu metotlar, başka çevresel problemlere neden olan büyük miktarda çamur üretmektedir. Koagülasyon ve flokülasyon gibi fizikokimyasal prosesler sadece kısmi bir çözüm sunmakta ve yasal gereksinimleri sağlamak için bu proseslerden sonra ikinci bir arıtım prosesi yer almalıdır [10].

\subsubsection{Adsorpsiyon}

Zeytinyağı endüstrisi atıksularına renk veren bileşenler, biyolojik olarak ayrışamayan bileşenler, bakteriler ve biyolojik arıtımı inhibe edici bileşikler aktif karbon kullanılarak adsorpsiyon yöntemi ile giderilmektedir. Adsorpsiyon yönteminde kullanılan aktif karbon yakıldığı için çok fazla katı atık oluşmaktadır. Ayrıca bu yakıtların yanması sonucunda oluşan yanma gazları da hava kirliliğine sebep olmaktadır. Ayrıca yetişmiş personele ihtiyaç vardır [33].

Kestioğlu vd. [11], asit kraking ve kimyasal koagülasyon işleminden sonra zeytinyağı atıksuyu örneklerini kullanarak granüler aktif karbon (Jacobi) ile adsorpsiyon çalışmasını yürütmüşlerdir. $10 \mathrm{~g} / \mathrm{L}$ adsorbent sırasıyla 8160, 4120, 1850, 1552 ve 724 mg/L KOİ başlangı̨̧ konsantrasyonuna sahip seyreltilmiş (sırasıyla 1/1, 1/2, 1/4, 1/5 ve 1/10 seyreltme oranı) örneklerle karıştırılmış ve çıkış KOİ değerleri sırasıyla 2672, 1820, 542, 486 ve 275 mg/L olarak ölçülmüştür. Bu çalışmada kullanılan granüler aktif karbonun adsorpsiyon kapasitesi granüler aktif karbon gramı başına $217 \mathrm{mg}$ KOİ ve 186 mg toplam fenol olarak bulunmuştur. Bu sonuçlar ön arıtılmış çıkış suyunun $\mathrm{m}^{3}$ ’ü başına yaklaşık $50 \mathrm{~kg}$ granüler aktif karbona ihtiyaç olduğunu göstermektedir.

Al-Malah vd. [50], çökelme, satrifüjleme ve filtrasyondan oluşan arıtma tesisi arıtma serisi ile zeytinyağı atıksularını arıtmışlardır. Filtrasyon çıkış suyu aktif kil ile adsorpsiyona maruz bırakılmıştır. Adsorpsiyon ile \%71 KOİ ve \%81 fenol içeriği giderilmiştir.

\subsubsection{Membran Prosesler}

Klasik ayırma prosesleri ile karşılaştırıldığında çok sayıda avantaj sunan membran prosesler son 10 yıldır gelecek vadeden teknoloji olarak görünmektedir [51]. Düşük enerji gereksinimi, madde ilavesine ihtiyaç olmaması, basit işletme şartları, ayırma verimi ve tesisi kolay büyütme imkanı membran ayırma proseslerinin önemli avantajlarıdır [52].

MF, UF, NF ve RO membranlar ve entegre membran prosesleri; hem zeytin fabrikas1 atıksularının çevreye güvenli deşarjı, sulama ve hatta zeytin fabrikasında geri dönüşüm ve kullanımı için kabul edilebilir kalitede çıkış suyu elde etmek hem de zeytin fabrikası atıksularından antioksidantların ve 
polifenollerin geri kazanımı, saflaştırma ve konsantre etme için önerilmektedir [53]. Özellikle iki veya daha fazla UF proseslerini takiben nihai NF proses önerilmektedir [52].

Membran prosesler, yüksek verim ve orta düzeyde yatırım ve işletme masraflarına rağmen konsantrasyon polarizasyon ve kirlenme olayı bu teknolojilerin uygulamasında hala temel sorun olarak devam etmektedir. Konsantrasyon polarizasyon membran sınır bölgesinde çözelti konsantrasyonunun artmasıyla meydana gelmekte, ilave dirence yol açmakta ve böylece işletme maliyetini artırmakta ve süzüntü akımının kalitesini de olumsuz etkilemektedir. Kompleks bir olay olan membran kirlenmesi membran gözeneklerin bloklanmasını, tıkanmasını ve membran üzerinde kek oluşumunu içermektedir [54]. Membran kirlenmesi sonucu olarak hızla ak1 düşüşü gözlenmekte ve membran performansı azalmaktadır. Membran seçiciliğinin değişmesine yol açmaktadır. Yerinde membran temizlemesi için sık sık tesis kapatma ihtiyacından dolayı işletme ve enerji maliyeti artmaktadır. Membran ömrünü azaltan tersinmez kirlenme erken membran modülü değiştirme ihtiyacından dolayı yatırım maliyetini önemli derecede artırmaktadır $[14,51,55,56]$. Membran kirlenmesi; membran karakteristikleri, çözeltilerin moleküler boyutu ve membranla etkileşimi gibi besleme çözeltisi özellikleri, işletme şartları (transmembran basıncı, çapraz akış hızı, işletme sıcaklığı) gibi faktörlere bağlıdır [14]. Membran modifikasyonu, süzüntü akısı ve antikirlenme bakımından membran performansını geliştirecek en etkili yollardan biridir [56]. Ochando-Pulido vd. [54], iki fazlı zeytin fabrikası atıksuların arıtımında kullandıkları RO membranda 15-25 bar işletme basıncında konsantrasyon polarizasyon ve kirlenme oluşmuştur. 35 bara çıkarıldığında beş kat artmıştır. Tersinmez kirlenmeden kaçınmak için çapraz akış hızı $5.09 \mathrm{~m} / \mathrm{s}$ 'e çıkarıldığında konsantrasyon polarizasyon ve kirlenme azalmıştır. Daha düşük sıcaklıkta önemli derecede az kirlenme gözlemlemişlerdir.

Zeytin işleme atıksularında askıda katı maddenin yüksek içeriği kirlenmeye neden olmakta ve membran ömrünü azaltmaktadır [57]. Bu nedenle membran kirlenmesini azaltmak ve proses verimini geliştirmek için uygun ön arıtım basamağı gereklidir [56, 57].

El-Abbasi vd. [57], çalışmalarında zeytin işleme atıksularının arıtımı için $50 \mathrm{kDa}$ moleküler ağırlığa sahip polietersülfon membran kullanmışlar ve UF membranın etkili bir ön arıtım olduğunu belirlemişlerdir. Böylece ön arıtım süzüntüden fenolik bileşiklerin ekstraksiyonunu etkili bir şekilde artırabilmekte ve sonrasında ikincil arıtma verimliliğini geliştirebilmektedir. Garcia-Castello vd. [58], tarafında yapılan çalışmada MF ön arıtımı ile askıda katı maddelerin \%91 ve toplam organik karbonun \%26’1 giderilmiş̧ir. MF süzüntüsü NF arıtıma tabi tutulmuş ve polifenol NF süzüntü akımında geri kazanılmış ve NF süzüntüsünda polifenol osmotik distilasyon ile konsantre edilmiştir.

Cassano vd. [55], farklı moleküler ağırlıklı ve polimerik malzemeye sahip UF membranlar kullanarak zeytin fabrikası atıksularından polifenolik ve antioksidant bileşikleri geri kazanmışlardır. Selüloz UF membranlar polietersülfon membranlardan süzüntü akımında daha fazla polifenol, daha yüksek süzüntü akımı ve daha düşük kirlenme indeksi içermiştir. Cassano vd. [59], iki UF membran prosesi takiben NF membranı çalışmışlardır. UF konsantresinin biyogaz üretimi için anaerobik çürütücüye gönderilebildiğini ve NF süzüntüsünün zeytin yağı ekstraksiyon prosesinde proses suyu ve entegre membran sistemde membran yıkama suyu olarak kullanılabildiğini belirtmişlerdir.

Turano vd. [14], zeytinyağı atıksularının arıtımında entegre santrifüj-UF sistemini kullanmışlardır. Santrifüj ve UF'nin kombinasyonu ile \%90 KOİ giderimi sağlanmıştır. Toplam katı 
madde azalması \%80 olmuştur. KOİ azalması uygun olmasına rağmen süzüntü suyu Avrupa yasaları için

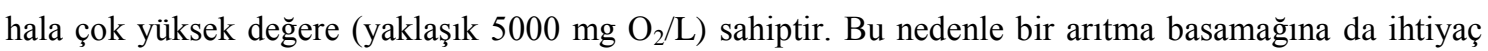
duyulmaktadir. Coskun vd. [60], NP010, NP030 ve NF270 nanofiltrasyon membranlar ve XLE ve BW30 ters osmoz membranlar kullanarak membran teknikleri ile zeytin fabrikaları atıksularının arıtımını araştırmışlardır. NP010, NP030 ve NF270 nanofiltrasyon membranlarda 10 barda elde edilen KOİ giderim verimi sirasıyla \%60.1, \%59.4 ve \%79.2 iken XLE ve BW30 ters osmoz membranlarda \%96.3 ve \%96.2 olmuştur. Ayrıca 25 bar basınçta iletkenlik giderimi XLE ve BW30 ters osmoz membranlarda sırasıly \%93.2 ve \%94.8 olmuştur.

\subsubsection{Elektrokoagülasyon}

Elektrokoagülasyon su ve atıksu arıtımında basit ve etkili elektrokimyasal metotlardan biridir. Elektrik yükleri tarafından kolloidlerin, süspansiyonların ve emülsiyonların stabilitesinin etkilenmesine dayanmaktadır. Eğer elektrik yükleri uygun elektrotlar yoluyla yüklü parçacıklara verilirse parçacıkların yüzey yükü nötürleştirilmekte ve partiküller birleşmektedir [61].

Elektrokoagülasyon, zeytinyağı üretim atıksuları ve diğer endüstriyel atıksuların arıtımı için son yıllarda dikkat çeken bir metottur [1]. Elektrokoagülasyon; aluminyum ya da demir elektrotlarından sırasıyla ya aluminyum ya da demir iyonları elektriksel olarak çözülerek yerinde koagülantların üretimini içermektedir. Metal iyonların oluşumu anotta yer almakta, hidrogen gazı katotdan salıverilmektedir. Hidrojen gazı, floklaşmış partiküllerin suyun yüzeyine çıkmasına da katkıda bulunmaktadır. Anotta yer alan kimyasal reaksiyonlar aşağıda verilmiştir. Gelişmeye başlayan $\mathrm{Al}^{3+}$ veya $\mathrm{Fe}^{2+}$ iyonları partikülleri floklaştırmada çok etkili koagülantlardır. Genellikle aluminyum su arıtımında ve demir atıksu arıtımında kullanılmaktadır [62].

Aluminyum anotta;

$$
\mathrm{Al}-3 \mathrm{e} \rightarrow \mathrm{Al}^{3+}
$$

Alkali şartlarda;

$$
\mathrm{Al}^{3+}+3 \mathrm{OH}^{-} \rightarrow \mathrm{Al}(\mathrm{OH})_{3}
$$

Asidik şartlarda;

$$
\mathrm{Al}^{3+}+3 \mathrm{H}_{2} \mathrm{O} \rightarrow \mathrm{Al}(\mathrm{OH})_{3}+3 \mathrm{H}^{+}
$$

Demir anotta;

$$
\mathrm{Fe}-2 \mathrm{e} \rightarrow \mathrm{Fe}^{2+}
$$

Alkali şartlarda;

$$
\mathrm{Fe}^{2+}+2 \mathrm{OH}^{-} \rightarrow \mathrm{Fe}(\mathrm{OH})_{2}
$$

Asidik şartlarda;

$$
4 \mathrm{Fe}^{2+}+\mathrm{O}_{2}+2 \mathrm{H}_{2} \mathrm{O} \rightarrow 4 \mathrm{Fe}^{3+}+4 \mathrm{OH}^{-}
$$

İlave olarak oksijen yayılım reaksiyonu vardır.

$$
2 \mathrm{H}_{2} \mathrm{O}-4 \mathrm{e} \rightarrow \mathrm{O}_{2}+4 \mathrm{H}^{+}
$$

Katotta reaksiyon;

$$
2 \mathrm{H}_{2} \mathrm{O}+2 \mathrm{e} \rightarrow \mathrm{H}_{2}+2 \mathrm{OH}^{-}
$$


$\mathrm{pH}$, kirletici tipi ve konsantrasyonu, kabarcık boyutu ve flok stabilitesi elektrokoagulasyon ünitesinin işletimini etkilemektedir [63]. Elektrokoagülasyonun avantajları yüksek derecede partikül giderim verimi, kompakt arıtma tesisi, nispeten düşük maliyet ve tam otomasyon imkanını içermektedir [62]. Klasik koagülasyon teknolojileri ile karşılaştırıldığında daha düşük hacimde çamur üretilmektedir [1]. Bu metot herhangi bir kimyasal madde uygulamaksızın zeytinyağı atıksularının arıtımına izin vermektedir. Elektrik enerjisi tüketimi yeterince düşüktür [9]. Biyolojik olarak bozunmayan organik maddeleri uzaklaştırabilme veya biyolojik arıtıma hazır hale getirme, hidroksitler şeklindeki çökelekler veya floklar üzerinde adsorpsiyonla ağır metal iyonlarını uzaklaştırabilme gibi avantajlara da sahiptir [64]. Askıda katı maddeler, yağ ve gres ve hatta floklaşabilen inorganik kirleticileri içeren atıksuların arıtımında elektrokoagülasyonun üstün performansı ispatlanmıștır [62].

İnan vd. [9], elektrot materyali olarak eş zamanlı olarak reaktörde aluminyum ve demir kullanarak elektrokoagülasyon ile zeytinyağı atıksularından KOİ, renk ve AKM giderimini araştırmışlardır. 30 dakika bekleme süresinde, $\mathrm{pH}=6.2$, ve $\mathrm{CD}=20 \mathrm{~mA} / \mathrm{cm}^{2}$ akım yoğunluğunda aluminyum elektrodu ile \%52, demir elektrodu ile \%42 KOİ giderimi elde edilmiştir. Akım yoğunluğu arttıkça \% KOİ giderimi de artmıştır. 10 dakika bekleme süresinde ve $10-40 \mathrm{~mA} / \mathrm{cm}^{2}$ akım yoğunluğu aralığında \%90-97 renk giderimi elde edilmiştir.

Tezcan-Ün vd. [61], yüksek KOİ konsantrasyonuna sahip zeytinyağı atıksularının arıtımında elektrokoagülasyon ile arıtımını araştırmışlardır. Elektrot olarak demir ve aluminyum, koagülant yardımcısı olarak polialüminyum klorur ve oksitleyici madde olarak $\mathrm{H}_{2} \mathrm{O}_{2}$ kullanmışlardır. Elektrot olarak $\mathrm{Fe}, \mathrm{Al}$ 'dan daha etkili bulunmuştur. $\mathrm{H}_{2} \mathrm{O}_{2}$ ve koagülant yardımcısı konsantrasyonlarına bağlı olarak 20-75 $\mathrm{mA} / \mathrm{cm}^{2}$ akım yoğunluğu aralığında KOİ giderim verimi \%62-86 iken yağ-gres ve bulanıklık giderimi $\% 100$ olmuştur. $\mathrm{Bu}$ tip atıksuların arıtımında koagulant yardımcısı ve oksidant yokluğunda elektrokoagülasyonun çok etkili olmadığı görülmüştür. Hanafi vd. [63], alüminyum elektrot kullanarak elektrokoagülasyon ile zeytin fabrikası atıksularının arıtımını incelemişlerdir. 15 dakika elektroliz süresi, $2 \mathrm{~g} / \mathrm{L} \mathrm{NaCl}$ konsantrasyonu, başlangıç $\mathrm{pH}=4.2$ ve $250 \mathrm{~A} / \mathrm{m}^{2}$ akım yoğunluğu şartında KOİ ve fenol giderimi \%70'i aşmıştır. Elektrot tüketimi $0.085 \mathrm{~kg} \mathrm{Al} / \mathrm{kg}$ giderilen KOİ ve tüketilen enerji $263 \mathrm{kWh} / \mathrm{kg}$ giderilen KOİ olmuştur.

Adhoum ve Monser [65], alüminyum elektrotları kullanarak zeytinyağı atıksuların arıtımında elektrokoagülasyon tekniğinin performansını araştırmışlardır. Optimum pH'nın 4-6 aralığında olduğunu bulmuşlardır. Akımdaki artış arıtma hızını önemli ölçüde arttırmıştır. Düşük bir maliyetle en hızlı arıtmaya izin veren optimum akım yoğunluğunu $75 \mathrm{~mA} / \mathrm{cm}^{2}$ olmuştur. Proses 25 dakika sonra \%76 KOİ, $\% 91$ polifenol, \%95 renk giderimi sağlamıştır. Elektrot tüketimi, arıtılmış zeytinyağı atıksularının $\mathrm{m}^{3}$ ’ü için $2.11 \mathrm{~kg}$ olarak bulmuşlardır. Sonuçlar, elektrokoagülasyonun zeytinyağı atıksuları arıtımında etkili alternatif bir çözüm olarak düşünülebileceğini ya da yüksek kalitede bir çıkış suyu sağlamak için klasik biyolojik prosesle birleştirilebileceğini göstermektedir.

García- García vd. [66], yemeklik sofra zeytini üretim atıksularının ön arıtımı için elektrokoagulasyon uygulamasını araştırmışlardır. Anotta aluminyum ve katotta demir kullanılarak 25 $\mathrm{mA} / \mathrm{cm}^{2}$ akım yoğunluğu ve $0.6 \mathrm{~cm}$ elektrotlar arası mesafe şartında 50 dakika arıtımdan sonra KOI giderimi \%40'a ulaşmıştır. Fenollerin çoğu ve çözeltinin rengi giderilmiştir. Atıksuyun $\mathrm{m}^{3}$ ’ü başına elektrik tüketimi $0.76 \mathrm{kWh}$ ve alüminyum kaybı $2.15 \mathrm{gr}$ olmuştur. 
Kartal vd. [67], zeytinyağı atıksularının elektrokoagülasyon prosesi ile arıtımını araştırmışlardır. Çelik elektrotlarla koagülasyonda $1000 \mathrm{mg} / \mathrm{L} \mathrm{NaCI}$ ve $33.75 \mathrm{~mA} / \mathrm{cm}^{2}$ işletme koşullarında 60 dakika sonunda \%61 KOİ, \%63 TOK ve \%52 toplam fenol giderimi elde edilmiştir. Alüminyum elektrotlarla $1000 \mathrm{mg} / \mathrm{L} \mathrm{NaCl}$ ve $22.5 \mathrm{~mA} / \mathrm{cm}^{2}$ akım yoğunluğunda 45 dakika sonunda \%4 KOİ ve \%34 toplam organik karbon (TOK) giderimi elde edilmiştir. Khoufi vd. [68], çalışmalarında elektrokoagulasyon ile zeytin fabrikası atıksularından \%33.6 çözünmüş KOİ, \%75 renk, \%76.2 toplam basit monomerler, \%71 katı madde ve $\% 75$ bulanıklık giderimi sağlamışlardır.

\section{3. İleri Oksidasyon Prosesleri}

Atıksularda toksik ve kalıcı özellikteki organik maddelerin bulunması son zamanlarda dünyada oldukça önem kazanan bir sorun olmaktadır. Bu tür atıksuların arıtımında kirleticilerin biyolojik olarak parçalanmaması nedeni ile klasik biyolojik arıtma yöntemleri çok etkili olmamaktadır. Fizikokimyasal yöntemler etkili olmasına rağmen kirleticinin bir ortamdan başka bir ortama geçirilmesinden dolayı pek tercih edilmemektedir. İleri oksidasyon prosesleri bu tür atıksuların arıtımında oldukça etkili yöntemler olarak önem kazanmaktadır [69]. İleri oksidasyon prosesleri ya bütün kirleticilerin $\mathrm{CO}_{2}, \mathrm{H}_{2} \mathrm{O}$ ve mineral tuzlara tam mineralizasyonu ya da biyolojik ayrışmaya dirençli kirleticilerin seçici giderimi ve biyolojik olarak ayrışabilen ara ürünlere dönüşümü için kullanılabilmektedir [8].

İleri oksidasyon prosesleri bir oksijen kaynağı ve bir enerji kaynağı tarafindan oluşturulan stabil olmayan ve reaktif türler olan hidroksil radikali oluşumunu ve davranışını içermektedir. Oksijen kaynağı genellikle ozon $\left(\mathrm{O}_{3}\right)$ veya hidrojen peroksit $\left(\mathrm{H}_{2} \mathrm{O}_{2}\right)$ ve enerji kaynağ $1 \mathrm{UV}$ veya solar enerjidir [1]. $\mathrm{OH}^{\bullet}$ radikali oldukça reaktiftir ve biyolojik olarak bozunmayan birçok doğal ve sentetik organik bileşiklerin oksidatif olarak parçalanma reaksiyonlarını gerçekleştirebilme, bu bileşikleri $\mathrm{CO}_{2}$ ve $\mathrm{H}_{2} \mathrm{O}$ 'a mineralize etme özelliğine sahip, seçici olmayan bir radikaldir [70]. Oksidant olarak $\mathrm{H}_{2} \mathrm{O}_{2}, \mathrm{O}_{3}$ veya $\mathrm{O}_{2}$ kullanan ileri oksidasyon prosesleri biyolojik olarak ayrışamayan organik kirleticileri içeren kirli yeraltı suları, yüzeysel sular ve atıksuların iyileştirilmesinde çok ümit vadeden tekniklerdir [22].

$\mathrm{Bu}$ prosesler ozonlama, UV 1şınlaması, fotokatalitik, Fenton reaktanı, elektrokimyasal oksidasyon, ıslak hava oksidasyonu yanında bunların çeşitli kombinasyonlarını içermektedir. Elektrokimyasal oksidasyon, fenton oksidasyonu, ozonlama ve fotokatalitik gibi prosesler uzun arıtma sürelerinden sonra bile kısmen kirlilik giderimi gerçekleştirebilir [8].

\subsubsection{Ozonlama}

Ozon, aromatik halkalar ve çift bağlar içeren bileşiklere seçici bir şekilde saldıran güçlü oksitleyici bir maddedir [1]. Ozon kuvvetli bir oksidant olmasına rağmen aşırı derecede konsantre zeytinyağı üretim atıksularını tam arıtma kabiliyetine sahip değildir. Çeşitli çalışmalar en uygun şartlarda bile zeytinyağı atıksularının ozonlama süresince sağlanan KOİ giderim boyutunun \%20-30'u aşmadığını göstermiş̧tir [8]. Ozonlama ile arıtımın dezavantajlarından biri maliyettir. Ayrıca stabilliği; tuzların varlığı, pH ve sıcaklıkla etkilenmektedir. Örneğin alkali çözeltiler ozon ayrışmasını hızlandırmaktadır [11].

Siorou vd. [71], ozon oksidasyonu ile zeytin fabrikası atıksularından 300 dakika ve 540 dakika reaksiyon süresinde sırasıyla $\% 50$ ve $\% 60$ fenol degradasyonunu elde etmişlerdir. Chedeville vd. [72], zeytin fabrikası atıksularının arıtımında kullanılan ozonlama prosesi ile $20{ }^{\circ} \mathrm{C}$ de $0,3 \mathrm{Nm}^{3} / \mathrm{st}$ gaz akış hızı 
ve giriş gazında $23 \mathrm{~g} / \mathrm{Nm}^{3}$ ozon konsantrasyonu şartında 40 dakika sonra fenolik bileşiklerin \% $\% 0^{\prime} \mathrm{i}$ ve KOİ'nin \%48'i giderilmiştir. Sonuçlar, zeytin fabrikası atıksularından fenolik bileşiklerin gideriminde ozonlamanın oldukça etkili bir metot olduğunu göstermiştir. Bazı fenolik bileşiklerin oksidasyona karşı dirençli olduğu gözlenmiştir. Onları gidermek için $\mathrm{O}_{3} / \mathrm{UV}, \mathrm{O}_{3} / \mathrm{H}_{2} \mathrm{O}_{2}$ gibi proseslerin kullanımı ilgi görmektedir. Kestioğlu vd. [11], zeytinyağı atıksularının arıtımında $\mathrm{O}_{3} / \mathrm{UV}$ prosesini kullanarak $\% 99$ KOİ ve \%99 fenol giderimi elde etmişlerdir.

\subsubsection{UV ıșınlaması}

$\mathrm{UV} / \mathrm{H}_{2} \mathrm{O}_{2}$ prosesi, hidrojen peroksitteki $\mathrm{O}-\mathrm{O}$ bağını ayırmak ve hidroksil radikallerini üretmek için UV ışımasını kullanmaktadır.

Radikal oluşumu: $\mathrm{H}_{2} \mathrm{O}_{2}+\mathrm{hv} \rightarrow 2 \mathrm{OH}^{\bullet}$

Yukarıda tanımlanan biçimde üretilen hidroksil radikalleri, moleküllerden hidrojen atomunu ayırarak organik moleküllere saldırabilmektedir. Hidroksil radikali ile organiklerin ayrışması aşağıdaki gibi tanımlanmışıı [11].

$$
\begin{aligned}
& \mathrm{OH}^{\bullet}+\mathrm{RH} \rightarrow \mathrm{H}_{2} \mathrm{O}+\mathrm{R}^{\bullet} \\
& \mathrm{R}^{\bullet}+\mathrm{H}_{2} \mathrm{O}_{2} \rightarrow \mathrm{ROH}+\mathrm{OH}^{\bullet} \\
& \mathrm{R}^{\bullet}+\mathrm{O}_{2} \rightarrow \mathrm{ROO}^{\bullet} \\
& \mathrm{ROO}^{\bullet}+\mathrm{RH} \rightarrow \mathrm{ROOH}+\mathrm{R}^{\bullet}
\end{aligned}
$$

UV ışığı ile gerçekleştirilen ileri oksidasyon proseslerinin en önemli problemlerinden biri ise UV lambasının yüksek derecede elektrik enerjisi gereksinimi olup, işletme masraflarının artmasına neden olmaktadır. Bu nedenden dolayı reaksiyon süresinin minimize edilmesi ve ayrıca diğer reaksiyon koşullarının ( $\mathrm{pH}$, kimyasal madde seçimi ve konsantrasyonu, kirletici/oksidant madde oranı vb.) optimize edilerek enerji gereksiniminin azaltılması gerekmektedir [69]. Önceki çalışmalar $\mathrm{UV} / \mathrm{H}_{2} \mathrm{O}_{2}$ performansı üzerinde ışınlama süresi ve UV ışığının etkisini ve fizikokimyasal parametrelerin etkisini gözlemişdir [73].

Kestioğlu vd. [11], zeytinyağı atıksuların arıtımında $\mathrm{UV} / \mathrm{H}_{2} \mathrm{O}_{2}$ prosesi kullanarak \%99 KOİ ve fenol giderimi elde etmişlerdir. Drouiche vd. [73], UF tekniği ve $\mathrm{UV} / \mathrm{H}_{2} \mathrm{O}_{2}$ prosesini birleştirerek zeytinyağı atıksularını arıtmışlardır. UF, zeytinyağı atıksularında bulunan kirleticileri önemli derecede azaltabilmiştir (KOİ giderimi \%94). Ancak süzüntü suyunda bulunan maddelerden dolayı ileri arıtma gerekmiştir. UF ve UV/ $\mathrm{H}_{2} \mathrm{O}_{2}$ kombinasyonu sonucunda son çıkış suyu $17 \mathrm{mg} / \mathrm{L}$ TOK ve $52 \mathrm{mg} / \mathrm{L} \mathrm{KOİ}$ içermiştir. Çıkış suyundan tam renk giderimi elde edilmiştir.

\subsubsection{Fenton Prosesi}

Hidrojen peroksit ve demir sülfat ilavesi (Fenton oksidasyonu) vasitasıly kimyasal oksidasyon ve koagülasyonu birleştiren oksidasyon prosesi gelecek vadeden bir teknolojidir. Bu proseste demir (III) ve demir (II) konsantrasyonu, peroksit konsantrasyonu, $\mathrm{pH}$ ve reaksiyon süresi gibi parametreler büyük öneme sahiptir. Fenton reaksiyonları kalıcı organikleri arıtabilmektedir [1]. 
Fenton oksidasyon prosesinde organik maddeler $\mathrm{FeSO}_{4}$ varlığında $\mathrm{H}_{2} \mathrm{O}_{2}$ ile reaksiyona girerek atıksudaki KOİ ve toksisite azalmaktadır. Yapılan çalışmalar sonucu Fenton oksidasyonun mekanizması bulunmuş ve asidik şartlar altında $\mathrm{H}_{2} \mathrm{O}_{2}$ 'den katalitik ayrışmayla hidroksil radikallerinin $\left(\mathrm{OH}^{\circ}\right)$ oluştuğu görülmüştür.

$$
\begin{aligned}
& \mathrm{H}_{2} \mathrm{O}_{2}+\mathrm{Fe}^{2+} \rightarrow \mathrm{Fe}^{3+}+\mathrm{OH}^{-}+\mathrm{OH}^{\bullet} \\
& \mathrm{RH}+\mathrm{OH}^{\bullet} \rightarrow \mathrm{R}^{\bullet}+\mathrm{H}_{2} \mathrm{O} \\
& \mathrm{R}^{\bullet}+\mathrm{Fe}^{3+} \rightarrow \mathrm{R}^{+}+\mathrm{Fe}^{2+} \\
& \mathrm{Fe}^{2+}+\mathrm{OH}^{\bullet} \rightarrow \mathrm{Fe}^{3+}+\mathrm{OH}^{-}
\end{aligned}
$$

Yukarıdaki reaksiyonlarda da görüldüğü gibi oksidasyon için hidrojen peroksit, $\mathrm{Fe}(\mathrm{II})$ ve organik maddeleri kullanmaktadır. Fenton prosesi dört basamaktan oluşmaktadır. Bunlar $\mathrm{pH}$ ayarlama, oksidasyon reaksiyonu, nötralizasyon ve koagülasyon ile çöktürme reaksiyonudur. Bu şekilde organik maddeler iki aşamada oksidasyon ve koagülasyon ile giderilmektedir [74].

Zeytinyağı üretim atıksuları genellikle düşük, mevsimsel atıksu debisine sahip olduğu için küçük fenton ünitesi üretilen çıkışs sularının etkili bir şekilde üstesinden gelmek için yeterli olacaktır. Fenton reaktanı ile zeytinyağı atıksularının arıtma maliyeti klasik biyolojik arıtma maliyetinden daha yüksektir. Çünkü $\mathrm{H}_{2} \mathrm{O}_{2}$ tüketimi işletme maliyetinin büyük bir kısmını oluşturmaktadır. Bu açıdan, kullanılan Fenton bileşikleri dozajını optimize etmek için çalışmalara ihtiyaç duyulmaktadır [8].

Kallel vd. [75], sıfir değerlikli demir ve hidrojen peroksit ile Fenton oksidasyonu ile zeytin fabrikası atıksuların ön arıtımını araştırmışlardır. $19 \mathrm{~g} / \mathrm{L}$ KOİ ve $5.2 \mathrm{pH}$ 'a sahip seyreltilmiş atıksular ile yürütülmüştür. $1 \mathrm{~g}$ KOİ giderimi için $0.06 \mathrm{M} \mathrm{H}_{2} \mathrm{O}_{2}$ 'e ihtiyaç duyulmuştur. $1 \mathrm{M} \mathrm{H}_{2} \mathrm{O}_{2}$ ile \%92 KOİ giderimi elde edilmiştir. Yüksek $\mathrm{H}_{2} \mathrm{O}_{2}$ ile KOİ giderimi artmamıştır. $\mathrm{pH}=1$ 'de 1 saatten sonra KOİ giderimi $\% 78$ olarak gözlenmiştir. 2 ve 4 pH değeri ile \%92 olmuştur. Kiril Mert vd. [76], Fenton ve Fenton-benzeri prosesler ile zeytinyağı üretim atıksuların arıtımını araştırmışlardır. Fenton için $\mathrm{pH}=3$, $\mathrm{H}_{2} \mathrm{O}_{2}=3500 \mathrm{mg} / \mathrm{L}(100 \mathrm{mM})$ ve $\mathrm{FeSO}_{4}=3000 \mathrm{mg} / \mathrm{L}(10.74 \mathrm{mM})$ olarak belirlenen optimum şartlarda $\% 81$ KOİ ve \%86 fenol giderimi elde etmişlerdir. Özdemir vd. [77], klasik Fenton prosesi (KFP) ve Fenton tipi proses (FTP) ile zeytinyağı atıksularından KOİ ve fenol giderimini araştırmışlardır. KFP için $\mathrm{Fe}^{2+}=1500$ $\mathrm{mg} / \mathrm{L}, \mathrm{H}_{2} \mathrm{O}_{2}=1750 \mathrm{mg} / \mathrm{L}$ ve $\mathrm{pH}=4.6$ ve FTP için $\mathrm{Fe}^{0}=2000 \mathrm{mg} / \mathrm{L}, \mathrm{H}_{2} \mathrm{O}_{2}=2000 \mathrm{mg} / \mathrm{L}$ ve $\mathrm{pH}=3$ olarak belirlenen optimum şartlar altında KFP ile $\% 82.4$ KOİ ve $\% 62$ fenol ve FTP ile $\% 82$ KOİ ve $\% 63.4$ fenol giderilmiştir. Nieto vd. [78], iki fazlı zeytinyağı ekstraksiyon prosesinden gelen zeytinyağı fabrikası atıksularının Fenton-benzeri proses ile arıtımında $\mathrm{pH}=3, \mathrm{H}_{2} \mathrm{O}_{2}$ konsantrasyonu=100 g/ $\mathrm{dm}^{3}, \mathrm{FeCI}_{3} / \mathrm{H}_{2} \mathrm{O}_{2}$ oranı $=0,04$ ve $281-285 \mathrm{~K}$ ortam sıcaklığında $\% 92.6$ KOİ ve $\% 99.8$ toplam fenol giderimi elde etmişlerdir. Hodaifa vd. [79], iki fazlı zeytinyağı ekstraksiyon prosesinden gelen zeytinyağı fabrikası atıksularından Fenton-benzeri proses ile $\mathrm{pH}=3, \mathrm{FeCI}_{3} / \mathrm{H}_{2} \mathrm{O}_{2}$ oranı=0,02-0,058 w/w, 0,3-0,4 g/ $\mathrm{dm}^{3} \mathrm{Fe}(\mathrm{III})$ konsantrasyonu ile ortam sıcaklığında $\% 97$ organik madde ve $\% 99$ fenolik bileşikler giderilmiştir.

\subsubsection{Foto-Fenton Prosesi}

Işıklı ortamda gerçekleşen Fenton reaksiyonları Foto-Fenton reaksiyonları olarak ifade edilir. $\mathrm{Fe}^{2+} / \mathrm{H}_{2} \mathrm{O}_{2} / \mathrm{UV}$ (Foto-Fenton) ve $\mathrm{Fe}^{3+} / \mathrm{H}_{2} \mathrm{O}_{2} / \mathrm{UV}$ (Foto-Fenton benzeri) reaktanlar ile organik kirleticinin bozunma hızı ve mineralizasyonu önemli derecede arttırılabilmektedir. UV 1şı̆̆ının proses verimini önemli derecede etkilediği bilinmektedir. Bunun en önemli sebeplerinden biri de UV ışığının etkisiyle 17 
nolu reaksiyonda görüldüğü üzere daha fazla $\mathrm{OH}^{\bullet}$ radikallerinin oluşması, fotokimyasal olarak $\mathrm{Fe}^{2+} \mathrm{e}$ indirgenen ve Fenton reaksiyonlarında tekrar $\mathrm{Fe}^{3+} \mathrm{e}$ yükseltgenen demir iyonlarının geri çevrimi nedeniyle daha az $\mathrm{Fe}^{2+} / \mathrm{Fe}^{3+}$ iyonuna ihtiyaç duyulmasıdır [70].

$$
\mathrm{Fe}(\mathrm{OH})^{2+}+\mathrm{h} v \rightarrow\left[\mathrm{Fe}(\mathrm{OH})^{2+}\right]^{*} \rightarrow \mathrm{Fe}^{2+}+\mathrm{OH}^{\bullet}
$$

UV veya solar enerji ile geliştirilmiş Fenton prosesi (Foto-Fenton) zeytinyağı atıksularının fenolik içeriğini azaltma yeteneği göstermiştir [1]. Foto-Fenton yöntemi, fenol gideriminde oldukça etkili olup fenolün biyolojik ayrışabilirliğini arttırmakta ve toksisitesini azaltmaktadır. Ayrıca arıtma esnasında biyolojik arıtma öncesi Foto-Fenton prosesinin ön arıtma olarak kullanılması önerilmektedir [69].

Badawy vd. [80], Foto-Fenton prosesini kullanarak $44250 \mathrm{mg} / \mathrm{L}$ TOK ve $11780 \mathrm{mg} / \mathrm{L}$ KOİ içeren zeytin fabrikası atıksularından kalıcı kirleticilerin arıtımını araştırmışlardır. $\mathrm{pH}=3,60$ dakika 1şınlama süresi, $\mathrm{H}_{2} \mathrm{O}_{2}=3 \mathrm{~g} / \mathrm{L}$ ve $\mathrm{Fe}^{2+}=0.2 \mathrm{~g} / \mathrm{L}$ olarak belirlenen optimum şartlarda $\% 87 \mathrm{KOI}, \% 84 \mathrm{TOK}$, $\% 97.44$ lignin ve $\% 98.31$ toplam askıda katı madde giderimi elde edilmiştir. BOİ ${ }_{5} / \mathrm{KOİ}$ oranı 0.19 'dan 0.88 'e kadar yükseltilmiştir.

\subsubsection{Elektro-Fenton Prosesi}

Elektro-Fenton metodu, elektrokimyasal proses ve Fenton oksidasyonunun kombinasyonunu temsil etmektedir. Kalıcı veya toksik atıksuları ayrıştırmak için ileri oksidasyon prosesinde hidrojen peroksitin bir oksidant olarak kullanılabilmesine dayanmaktadır. 14 nolu reaksiyonda görüldüğü gibi Fe iyonu $\mathrm{H}_{2} \mathrm{O}_{2}$ ile reaksiyona girdiğinde kuvvetli oksidant olan hidroksil radikalini $\left(\mathrm{OH}^{\bullet}\right)$ oluşturacaktır.

$$
\mathrm{Fe}^{2+}+\mathrm{H}_{2} \mathrm{O}_{2} \rightarrow \mathrm{Fe}^{3+}+\mathrm{OH}^{\bullet}+\mathrm{OH}^{-}
$$

Fenton reaktanı olarak bahsedilen, bu $\mathrm{Fe}^{2+} / \mathrm{H}_{2} \mathrm{O}_{2}$ sistemi $\mathrm{OH}^{\bullet}$ radikali yanında $\mathrm{Fe}^{2+} / \mathrm{Fe}^{3+}$ koagülasyonun ikili fonksiyonuna sahiptir. Bu proses esnasında polifenoller gibi atıksularda mevcut olan biyolojik olarak ayrışamayan organikler ve toksik kirleticiler genellikle hidroksil radikali gibi oksidantların üretimi ve maddenin flokülasyonunu geliştiren kompleks koagülantlar yoluyla doğrudan veya dolaylı anodik oksidasyon ile yok edilmektedir [15].

Khoufi vd. [15], Elektro-Fenton prosesini takip eden anaerobik biyoarıtımdan oluşan birleşik bir proses ile zeytinyağı atıksularının arıtımını çalışmışlardır. Elektro-Fenton prosesi ile toplam fenolik bileşiklerin $\% 65.8$ 'i giderilmiştir. Zeytinyağı atıksuların toksisitesi \%100'den \%66.9'a kadar düşürülmüştür. Birleşik proseste KOİ, askıda katılar, polifenoller ve lipit içeriği bakımından yüksek giderim elde edilmiştir.

\subsubsection{Elektrokimyasal Oksidasyon}

Son zamanlarda yeni elektrot materyallerin gelişimi ve daha kompakt reaktörler sayesinde elektrokimyasal oksidasyonun; tekstil çıkış suları, deponi alanı sızıntı suları, deri atıksuları ve oto yıkama atıksuları gibi biyolojik olarak ayrışamayan organik maddeler içeren atıksuların etkili oksidasyonu için ümit verici ve cazip bir teknik olduğu ispatlanmıştır. Özellikle iyi iletkenliğe sahip olan ve klorür iyonları 
içeren zeytinyağı atıksularının arıtımında elektrokimyasal metotların çok etkili olduğu rapor edilmiştir. Çünkü organik kirleticiler ya elektrot-çözelti arafazında doğrudan oksidasyonla ya da aktif klorün elektrik üretimiyle temel çözeltide dolaylı oksidasyonla oksitlenmektedir [10].

Geçmişte, grafit nispeten ekonomik olduğu ve tatmin edici sonuçlar verdiği için elektrokimyasal arıtma esnasında anot olarak sıklıkla kullanılmıştır. Son zamanlarda elektrooksidasyon için titanyum elektrotlar kullanılmaktadır. Platinyum dışında, rutenyum ve radyum atıksularda bulunan kirleticilerin elektrooksidasyonunda elektrokatalizörler olarak da uygulanabilir. Fenoller ve surfaktantlar gibi biyolojik olarak elimine edilmesi zor olan organik kirleticileri yok etmek mümkündür. İridyum karışımları bu amaçlar için başarılı bir şekilde kullanılmaktadır.

Atıksularda kloridler mevcut olduğunda, dolaylı anodik oksidasyon kuvvetli oksidantlar ile meydana gelmektedir. En önemli oksidantlardan bazıları oksijen, klor, hidroksil radikalleri ve ozondur. $\mathrm{Bu}$ oksidantlar oksitlenebilen organik kirleticilerin çeşitli türlerini içeren endüstriyel atıksuları oksitlemede etkilidir. Oksidasyonun süresi; bileşiklerin stabilitesi ve konsantrasyonu, kullanılan NaCI konsantrasyonu, sıcaklık, çözelti pH'ı, anot boyutu ve uygulanan akım ve voltaja bağlıdır. Radikaller yüksek oksidasyon potansiyelinden dolayı kısa bir ömre sahiptirler. Ya başka oksidantlara $\left(\mathrm{CI}_{2}, \mathrm{O}_{2}, \mathrm{CIO}_{2}\right.$, $\mathrm{O}_{3}$ ve $\mathrm{H}_{2} \mathrm{O}_{2}$ ) ayrıştırılmakta ya da organik bileşikleri oksitlemektedirler (doğrudan degradasyon). Radikallerin yok olmasında açığa çıkan birincil $\left(\mathrm{CI}_{2}, \mathrm{O}_{2}\right)$ ve ikincil oksidantlar $\left(\mathrm{CIO}_{2}, \mathrm{O}_{3}\right.$ ve $\left.\mathrm{H}_{2} \mathrm{O}_{2}\right)$ oldukça uzun bir ömre sahipler ve oksidasyon işlemini devam ettirerek elektrotlardan uzak alana yayılmaktadırlar (dolaylı oksidasyon).

Organik kirleticilerin doğrudan oksidasyonu anodun katalitik aktivitesine, anodun aktif noktalarına, organik kirleticilerin difüzyonuna ve uygulanan akım yoğunluğuna bağlidır. Dolaylı elektrooksidasyon hızı; ikincil oksidantların çözelti içine yayılma hızları, sıcaklık ve pH'a bağlıdır. Etkili kirletici degradasyonu doğrudan elektrokimyasal prosese dayanmaktadır. Çünkü ikincil oksidantlar bütün organikleri suya ve $\mathrm{CO}_{2}$ ' e tam olarak dönüştüremezler [31].

Panizza ve Cerisola [10], karışı titanyum ve rutenyum oksit $\left(\mathrm{Ti} / \mathrm{TiRuO}_{2}\right)$ anotlarını kullanarak, zeytinyağı atıksularından KOİ, renk ve aromatiklerin giderimi için elektrokimyasal arıtmayı çalışmışlardır. \%80 KOİ giderimi, hemen hemen renk ve aromatik bileşiklerin tam giderimini elde etmişlerdir. KOİ işletme şartlarıyla etkilenmiştir. Özellikle atıksuya $5 \mathrm{~g} / \mathrm{L} \mathrm{NaCI}$ ilavesi ve uygulanan yüksek akım (5A) ile desteklenmiştir. Aromatik içeriğin tam giderimi için spesifik enerji tüketimi $(0.18$ $\mathrm{kWh} / \mathrm{L}) \mathrm{KOİ} \mathrm{giderimi} \mathrm{için} \mathrm{gerekenden}(0.8 \mathrm{kWh} / \mathrm{L})$ önemli derecede daha düşüktür. Belaid vd. [20], elektrokimyasal oksidasyon ile zeytinyağı atıksularından \%90'dan daha fazla renk ve yaklaşık \%85 fenol giderimi sağlamışlardır. Israilides vd. [31], zeytinyağı atıksuların arıtımını anot olarak Ti/Pt ve katot olarak paslanmaz çelik 304 kullanarak elektrokimyasal metotla çalışmışlardır. Elektrolit olarak \%4 NaCI atıksuya ilave etmişlerdir. $0.26 \mathrm{~A} / \mathrm{cm}^{2}$ akım yoğunluğunda 1 ve 10 saat elektrolizden sonra toplam KOİ giderimi sirasiyla $\% 41$ ve $\% 93$ olmuştur. TOK $\% 20$ ve $\% 80.4$, toplam fenolik bileşikler $\% 50$ ve $\% 99.4$, uçucu askıda katı madde $\% 1$ ve $\% 98.4$ azalmıştır. Ortalama enerji tüketimi 1 saatte giderilen KOI'nin kg'1 başına $1.273 \mathrm{kWh}$ ve 10 saatte giderilen KOİ'nin kg'1 başına $12.3 \mathrm{kWh}$ 'tir. Bu sonuçlardan zeytinyağı atıksuların toplam oksidasyonunda bu metodun uygun olmadığı görülmektedir. Ancak atıksuyun toksisitesinin gideriminde oksidasyon ön arıtma kademesi olarak kullanılabilir. Gotsi vd. [81], $\mathrm{NaCl}$ ile 5-20 kat seyreltilen zeytinyağı atıksularının Ti-Ta-Pt-Ir anot üzerinde elektrokimyasal 
oksidasyonunu araştırmışlardır. 60 dakika arıtmadan sonra fenolun renk gideriminin tam olduğunu, KOİ gideriminin \%40'ı aşmadığını belirtmişlerdir. Arıtılmış zeytinyağı atıksularının toksisitesinin arttığını ifade etmişlerdir. $\mathrm{Bu}$, organik klorlu yan ürünlerin üretimiyle alakalıdır.

Zeytin fabrikası atıksuları doğrudan ve dolaylı anodik oksidasyonun kombinasyonuyla arıtılabildiği için NaCl'e dayalı elektrokimyasal oksidasyon, potansiyel olarak uygun maliyetli bir arıtım sunmaktadır. Dolaylı anodik oksidasyon klor, hidroksil radikali ve oksijen gibi etkili oksidantların yerinde üretimi yoluyla meydana gelmektedir. Elektrolit olarak $\mathrm{NaCl}$ kullanımıyla ilişkili dezavantaj zeytinyağı atıksularını uzaklaştırmadan önce çıkış sularında giderilmesi gereken toksik organik klorlu yan ürünlerin olası oluşumudur [8].

\subsubsection{Fotokatalitik}

$\mathrm{TiO}_{2}$ 'nin ucuz olması, stabil olması ve sudaki zararı organik bileşikleri UV ışınlaması altında oksijen, su ve $\mathrm{CO}_{2}$ gibi zararsız bileşiklere dönüştürmesi nedeniyle literatürde en çok kullanılan yarı iletken maddedir. $\mathrm{UV} / \mathrm{TiO}_{2}$ fotokatalitik oksidasyon prosesi temel olarak solar enerji (hv) ile $\mathrm{TiO}_{2}$ yüzeyinde elektron (e) ve hol $\left(\mathrm{h}^{+}\right)$çiftinin ayrılarak katalizör yüzeyinde maddeler ile çeşitli reaksiyonlar vermesine dayanmakta ve temel olarak aşağıdaki şekilde ifade edilmektedir.

$$
\mathrm{TiO}_{2}\left(\mathrm{e}^{-}-\mathrm{h}^{+}\right) \rightarrow \mathrm{e}^{-}+\mathrm{h}^{+}
$$

UV ışınlaması ile oluşan elektron ve holler aşağıdaki reaksiyon eşitlikleri ile açıklandığı şekilde hidroksil radikali $\left(\mathrm{OH}^{\bullet}\right)$ oluşturabilirler:

$\mathrm{e}^{-}$reaksiyonları

$$
\begin{aligned}
& \mathrm{O}_{2}+\mathrm{e}^{-} \rightarrow \mathrm{O}_{2}^{-} \\
& \mathrm{O}_{2}+2 \mathrm{e}^{-}+2 \mathrm{H}^{+} \rightarrow \mathrm{H}_{2} \mathrm{O}_{2} \\
& \mathrm{H}_{2} \mathrm{O}_{2}+\mathrm{e}^{-} \rightarrow \mathrm{OH}^{\bullet}+\mathrm{OH}^{-} \\
& \mathrm{H}_{2} \mathrm{O}_{2}+\mathrm{h} v \rightarrow 2 \mathrm{OH}^{\bullet}
\end{aligned}
$$

$\mathrm{h}^{+}$reaksiyonları

$$
\begin{aligned}
& \mathrm{H}_{2} \mathrm{O}+\mathrm{h}^{+} \rightarrow \mathrm{OH}^{\bullet}+\mathrm{H}^{+} \\
& \mathrm{OH}^{-}+\mathrm{h}^{+} \rightarrow \mathrm{OH}^{\bullet}
\end{aligned}
$$

Hidroksil radikali çok güçlü bir oksitleyicidir ve sudaki pek çok madde ile reaksiyona girerek organik maddelerin $\mathrm{CO}_{2}$ 'e oksidasyonunda önemli rol oynamaktadır. Fakat diğer taraftan süspansiyon haldeki $\mathrm{TiO}_{2}$ katalizörünün sudan ayrılması oldukça zordur ve solar enerjinin maksimum $\% 10$ 'u $\mathrm{TiO}_{2}$ yüzeyinde kullanılabilmektedir. Son yıllarda çeşitli yüzeylere tutturulmuş $\mathrm{TiO}_{2}$ kullanılmaya başlanılmış olması $\mathrm{TiO}_{2}$ 'nin sudan ayrılması problemini çözse de bu $\mathrm{TiO}_{2}$ 'nin solar enerjiyi kullanma potansiyelini artırmamaktadır [82].

Büyük miktarda zeytinyağı üreten ülkelerin yıl boyunca yüksek şiddetteki solar 1şınlamadan faydalandığı düşünüldüğünde solar enerji kullanan fotokatalitik, zeytinyağı atıksularının arıtımı için 
gelecek vadeden ve uygun maliyetli bir metottur. Proses verimini artırmak için flokulasyon ve/veya dekantasyon gibi bir ön arıtma askıda katıları gidermek için kullanılmıştır. Çünkü askıda katılar sıvıya giren 1şı̆̆a engel olmaktadır [8].

Badawy vd. [80], başlangıç TOK değeri 44250 mg/L ve KOİ değeri 117860 mg/L olan zeytin fabrikası atıksularının arıtımını heterojen fotokatalitik oksidasyon olarak UV/yarı-iletken katalizör $\left(\mathrm{TiO}_{2}\right.$, $\mathrm{ZrO}_{2}$ ve Fe-Al'dan oluşan komposit katalizör) kullanarak çalışmışlardır. Hem KOİ hem de TOK gideriminde $\mathrm{TiO}_{2}$ diğerlerine göre daha etkili olmuştur. $\mathrm{pH}=8,60$ dakika 1şınlama süresi, $\mathrm{TiO}_{2}=2 \mathrm{~g} / \mathrm{L}$ optimum şartlarda \%71.2 KOİ, \%69 TOK, \%40.19 lignin ve \%49 toplam askıda katı madde giderimi elde edilmiştir. BOİ $/$ KOİ oranı 0.19'dan 0.66'a kadar çıkarılmıştır. El Hajjouji vd. [83], zeytinyağı fabrikası atıksularının $\mathrm{UV} / \mathrm{TiO}_{2}$ ile arıtımında 24 saatlik arıtmadan sonra \%22 KOİ, \%57 renk ve \%94 fenol giderimi elde etmişlerdir.

\subsubsection{Islak Hava Oksidasyonu}

Yüksek sıcaklık ve basınç altında oksijen kullanan oksidasyona islak hava oksidasyonu denilmektedir. Katalizörlü ve katalizörsüz ıslak hava oksidasyonu zeytinyağı atıksularının biyolojik olarak ayrışabilirliğini geliştirebilmektedir [1]. Islak hava oksidasyonu gibi yüksek basınçlı, yüksek sıcaklıklı prosesler nispeten kısa arıtma sürelerinde yüksek KOİ giderimleri sağlayabilmektedir. Temel dezavantajı gereken ağır şartlardan dolayı ıslak hava oksidasyonun kurulmasının ve işletilmesinin pahalı bir proses olmasıdır. Yüksek yatırım ve işletme maliyetleri, kullanılan yüksek basınç ve ağır işletme şartları altında meydana gelen yüksek korozyon hızlarına dirençli olması gereken yapı malzemelerinin kullanımıyla ilişkilidir. Diğer taraftan zeytinyağı atıksularında tipik olarak bulunan organik yük ile termal olarak dış desteğe ihtiyaç duymayan proses olduğu için yüksek sıcaklıkla ilgili maliyet büyük bir sorun değildir [8]. Islak hava oksidasyonu kalifiye işletmenlere ihtiyaç duyan karmaşık bir teknolojidir [20].

Gomes vd. [84], zeytin fabrikası atıksuların arıtımında katalitik ıslak hava oksidasyonunun uygunluğunu araştırmışlardır. Karbon destekli platinyum ve iridyum katalizörler 6.9 barlık oksijen kısmi basıncı altında 100 ve $200{ }^{\circ} \mathrm{C}$ 'de yürütülmüştür. $100{ }^{\circ} \mathrm{C}$ 'de kalıcı organik bileşikler uzun reaksiyon süresinde bile ( 8 saat) dayanıklı olmuştur. $200{ }^{\circ} \mathrm{C}$ 'de $\mathrm{Pt} / \mathrm{C}$ katalizör ile 8 saatlik reaksiyon süresinden sonra toplam organik karbon ve renk giderimi tam olarak elde edilmiştir.

\subsection{Birleşik Prosesler}

Benitez vd. [36], ozonlama, aerobik biyodegradasyon ve her iki arıtmanın kombinasyonu ile zeytin fabrikası atıksularının arıtımını araştırmışlardır. İki birleşik proses ile elde edilen giderim verimleri aynı işletme şartları altında tek proses ile sağlanılan giderim verimlerinden daha yüksek olmuştur. Aerobik biyodegradasyonu takiben ozonlama ile \%81.8 KOİ giderimi sağlanırken ozonlamayı takiben aerobik biyodegradasyon ile \%84.6 KOİ giderimi sağlanmıştır. Drouiche vd. [73], UF ve $\mathrm{UV} / \mathrm{H}_{2} \mathrm{O}_{2}$ tekniklerini birleştirerek giderim kapasitelerini incelemişlerdir. Sadece UF ile KOİ 30000 mg/L'den 1800 mg/L’e kadar azaltılarak \%94 KOİ giderim verimi elde edilmiştir. UV/ $\mathrm{H}_{2} \mathrm{O}_{2}$ ile ilave arıtım KOİ değerini yasal gereksinimlerden daha düşük olan $52 \mathrm{mg} / \mathrm{L}$ 'e kadar azaltmıştır. Yahiaoui vd. [85], ultrafiltrasyon ve elektrokoagulasyon proses kombinasyonunu kullanarak zeytin fabrikası atıksularından KOİ giderimini araştırmışlardır. UF prosesi ile KOİ \%96 giderim ile 28000 mg/L’den 1100 mg/L'e kadar azalmıştır. 
Ancak elde edilen bu değerler atıksu deşarj standartlarından yüksek olmuştur. UF çıkış suyu elektrokimyasal reaktörde arıtılmış ve $93.3 \mathrm{~A} / \mathrm{m}^{2}$ akım yoğunluğunda ve $4.5-6.5 \mathrm{pH}$ aralığında optimum KOİ giderimi elde edilmiştir. KOİ $1100 \mathrm{mg} / \mathrm{L}$ 'den 78 mg/L'e kadar azalmıştır.

Kotsou vd. [86], sofra zeytini işleme atıksularını Aspergillus niger kullanarak aerobik biyolojik arıtım ve Fenton prosesi kombinasyonunu kullanarak arıtımını araştırmışlardır. 2 günlük hidrolik bekleme süresi ile KOI $\% 70$, basit fenolik bileşikler $\% 85$ ve toplam fenolik bileşik $\% 41$ giderilmiştir. Kimyasal oksidasyonunun temel etkisi biyolojik arıtım esnasında dayanıklı olan fenolik bileşiklerin eliminasyonudur. Zorpas ve Costa [87], Fenton ile zeytinyağı atıksuların arıtımını ve arıtılmış atıksu ile zeytinyağı katı kalıntılarının birlikte kompostlanmasını çalışmışlardır. Fenton prosesi ile \%70 kadar KOİ giderimi elde edilmiştir. Fenton ile arıtılmış atıksu ile zeytinyağı katı atığının kompostlanmış materyali tarımsal amaçlar için uygun olmuştur. Dhouib vd. [88], zeytin fabrikası atıksularından kalıcı kirleticilerin arıtımı için fungal ön arıtma (Phanerochoete chrsosporium), anaerobik parçalama ve UF'den ibaret olan entegre bir teknoloji kullanmışlardır. Phanerochoete chrsosporium atıksuların toksisitesini \%100'den \%74'e düşürmüştür. Anaerobik parçalama çıkış suyu arıtılmamış atıksuya göre \%38'e düşmüştür. Son arıtma olarak UF kullanımı anaerobik çıkış suyu toksisitesini tamamen gidermiş ve yüksek moleküler ağırlıklı polifenoller tam giderilmiştir. Khoufi vd. [89], Elektro-Fenton, anaerobik ayrışma ve UF kombinasyonunu kullanmışlardır. Elektro-Fenton prosesi KOİ (\%50) ve monofenolik bileşiklerin yüksek giderimini (\%95) sağlamıştır. Bu ön arıtma yukarı akışlı anaerobik filtrenin anaerobik aktivitesini artırmıştır. Biyoreaktörde 4.5 günlük hidrolik bekleme süresi ve $10 \mathrm{~g}$ KOİ/L.G organik yükleme hızında \%75 KOİ giderim verimine ulaşılmıştır. Son arıtma olarak UF, anaerobik çıkış suyunu tamamen toksiksiz hale getirmiş ve yüksek moleküler ağırlıklı polifenolleri gidermiştir.

\section{Sonuc}

Akdeniz Ülkelerinde en önemli çevresel problemlerden biri olan zeytinyağı üretim tesisi atıksuları kolayca biyolojik olarak ayrışamayan organik maddeler, fitotoksik madde, çeşitli fenol ve fenolik bileşikler içermektedir. Arıtılmamış veya yetersiz şekilde arıtılmış zeytinyağı atıksuları çevreye deşarj edildiğinde sucul yaşamı tehdit etme, koku problemi, suları renklendirme ve toksisite gibi olumsuz çevresel etkilere neden olmaktadır. Zeytinyağı üretim tesislerinin kü̧̈ük ölçekli ve dağınık olması, üretimin sezonluk olması, teknik ve ekonomik nedenler, yüksek ve çeşitli organik yükler gibi pek çok faktör zeytinyağı atıksularının arıtımını güçleştirmektedir. Sıkı çevre yasaları ve uygulamalarından dolayı zeytinyağı atıksuların arıtımı konusunda çalışmalar yürütülmüş ve farklı metotlar önerilmiştir. Fakat bu metotların çoğu verim, pratikte uygulanabilirlilik ve maliyet açısından yetersiz kalmıştır.

Nispeten ucuz olan ve vasıfsız iş gücü ile işletilebilen lagünlerde buharlaştırma zeytinyağı atıksularının arıtımında en yaygın şekilde kullanılan bir uygulamadır. Ancak, bu uygulama geniş alan gereksinimi, kötü koku, yüzeysel ve yeraltı sularına sızma, böcek çoğalması gibi sorunlara neden olmakta ve bu uygulama ile gerekli deşarj standartlarını sağlamak mümkün olmamaktadır. Uygun maliyetli ve çevre dostu olan biyolojik proseslerde fenolik bileşiklerin inhibisyon etkisinden dolayı genellikle arıtım uzun sürmekte ve organik kirlilik tamamen giderilememektedir. Başka atıksularla zeytinyağı üretim atıksularını birlikte arıtma her bir atıksuyu ayrı ayrı arıtmaktan daha ekonomik olabilir. Ekonomik ve ekolojik açıdan kabul gören kompostlama, atıksu ve pirinanın herhangi bir fitotoksik etki olmaksızın 
gübre olarak kullanımını sağlamaktadır. Ultrafiltrasyon, nanofiltrasyon, ters osmoz, iyon değiştirme ve adsorpsiyon gibi teknikler kirleticileri yok etmemek sadece atıksudan katı yüzeyine kirletcileri transfer etmektedir. Ultrasfiltrasyon, nanofiltrasyon gibi membran prosesler ile zeytinyağı üretim atıksuların antioksidant maddeleri ve polifenolik bileşikleri geri kazanmak mümkündür. İleri oksidasyon prosesleri, zeytinyağı atıksularında mevcut olan ayrışması zor olan kirleticileri mineralize etme kabiliyetlerine sahip proseslerdir. Ancak bu proseslerin pahalı sistemler olması pratikte uygulanabilirliliğini kısıtlamaktadır.

Zeytinyağı atıksularının toksik maddeler içermesinden ve yüksek kirlilik yükünden dolayı tek kademeli biyolojik veya kimyasal proseslerin tam mineralizasyon sağlaması mümkün görünmemektedir. Zeytinyağı atıksuların arıtımında istenilen kalitede çıkış suyu elde etmek ve gerekli deşarj standartlarına ulaşabilmek için biyolojik, fizikokimyasal veya ileri oksidasyon proseslerin kombinasyonu üzerinde çalışmalar yürütülmektedir. Zeytinyağı atıksuların arıtımı için en uygun yöntem seçildiğinde yatırım ve işletme maliyeti, verim, yöntemin pratikte uygulanabilirliliği ve yasal mevzuat gibi hususlar göz önünde bulundurularak karar verilmelidir.

\section{Kaynaklar}

[1] Paraskeva P., Diamadopoulos E., "Technologies for olive mill wastewater (OMW) treatment: a review”, Journal of Chemical Technology and Biotechnology, 81, 1475-1485, 2006.

[2] Erses Yay A.S., Oral H.V, Onay T.T., Yenigün O., "A Study on olive oil mill waswater management in Turkey: a questionnaire and experimental approach", Resources, Conservation and Recycling, 60, 64-71, 2012.

[3] Azbar N., Bayram A., Filibeli A., Muezzinoğlu A., Sengul F., Ozer A., "A Review of Waste Management Options in Olive Oil Production", Criticial Reviews in Environmental Science and Technology, 34, 209-247, 2004.

[4] FAIR CT96-1420, Annex 2. "Final Report, İmprolive, Investments of Treatment and Validation of Liquid-Solid Waste from the Two Phase Olive Oil Extraction”, 2000.

[5] Borja R., Alba J., Banks C.J., "Impact of the main phenolic compounds of olive mill wastewater (OMW) on the kinetics of acetoclastic methanogenesis", Process Biochemistry, 32(2), 121-133, 1997.

[6] Taralas G., Kontominas M.G., "Thermochemical treatment of solid and wastewater effluents originating from the olive oil food industry”, Energy \& Fuels, 19, 1179-1185, 2005.

[7] Borja R., Rincón B., Raposo F., “Anaerobic biodegradation of two-phase olive mill solid waste and liquid effluents: kinetic studies and process performance- review”, Journal of Chemical Technology and Biotechnology, 81, 1450-1462, 2006.

[8] Mantzavinos D., Kalogerakis N., "Treatment of olive mill effluents, part I. organic matter degradation by chemical and biological processes-an overview", Environment International, 31, 289-295, 2005.

[9] İnan H., Dimoglo A., Şimşek H., Karpuzcu M., "Olive oil mill wastewater treatment by means of electro-coagulation", Separation and Purification Technology, 36, 23-31, 2004. 
[10] Panizza M., Cerisola G., "Olive mill wastewater treatment by anodic oxidation with paralel plate electrodes”, Water Research, 40, 1179-1184, 2006.

[11] Kestioğlu K., Yonar T., Azbar N., "Feasibility of physico-chemical treatment and advanced oxidatoin processes (AOPs) as a means of pretreatment of olive mill effluent (OME), Process Biochemistry, 40, 2409-2416, 2005.

[12] SKKY, Su Kirliliği Kontrolü Yönetmeliği, 31.12.2004 Tarih ve 25687 Sayılı Resmi Gazete, 2004.

[13] Oktav, E., Çatalkaya, E.Ç., Şengül, F., 2003, “Zeytinyağı endüstrisi atıksularının kimyasal yöntemlerle arıtımı", DË̈ Mühendislik Fakültesi Fen ve Mühendislik Dergisi, 5(3), 11-21, 2003.

[14] Turano E., Curcio S., De Paola M.G., Calabrò V., Iorio G., "An integrated centrifugationultrafiltration system in the treatment of olive mill wastewater", Journal of Membrane Science, 29, 519-531, 2002.

[15] Khoufi S., Aloui F., Sayadi S., "Treatment of olive oil mill wastewater by combined process electro-fenton reaction and anaerobic digestion”, Water Research, 40, 2007-2016, 2006.

[16] Oktav E., Özer A., "Zeytinyağı üretimi atıksularının fiziksel arıtımı”, I.Ulusal Çevre Kongresi, Cumhuriyet Üniversitesi Çevre Mühendisliği Bölümü, Sivas, 235-240, 2004.

[17] El-Shafey E.I., Correia P.F.M., de Carvalho M.R., "An integrated process of olive mill wastewater treatment”, Separation Science and Technology, 40, 2841-2869, 2005.

[18] Fakharedine N., Hajjouji H.E., Badi G.A., Revel J.C, Hafidi M., "Chemical and spectroscopic analysis of organic matter transformation during aerobic digestion of olive-mill waste-waters", Process Biochemistry, 41(2), 398-404, 2006.

[19] Sassi A.B, Boularbah A., Jaouad A., Walker G., Boussaid A., "A comparison of olive oil mill wastewaters (OMW) from three different processes in Morocco", Process Biochemistry, 41, 74$78,2006$.

[20] Belaid C., Kallel M., Khadhraou M., Lalleve G., Elleuch B., Fauvarque J.F., "Electrochemical treatment of olive mill wastewaters: removal of phenolic compounds and decolourization", Journal of Applied Electrochemistry, 36, 1175-1182, 2006.

[21] Fadil K., Chahlaoui A., Ouahbi A., Zaid A., Borja R., "Aerobic biodegradation and detoxification of wastewaters from the olive oil industry", International Biodeterioration \& Biodegradation, 51, 37-41, 2003.

[22] Ahmadi M., Vahabzadeh F., Bonakdarpour B., Mofarrah E., Mehranian M., "Application of the central composite design and response surface methodology to the advanced treatment of olive oil processing wastewater using fenton's peroxidation", Journal of Hazardous Materials, B123, 187-195, 2005.

[23] Fiorentino A., Gentili A., Isidori M., Lavorgna M., Parrella A., Temussi, F., "Olive oil mill wastewater treatment using a chemical and biological approach", Journal of Agricultural and Food Chemistry, 52, 5151-5154, 2004. 
[24] Lanciotti R., Gianotti A., Baldi D., Angrisani R., Suzzi G., Mastrocola D., Guerzoni M.E., "Use of Yarrowia lipolytica strains for the treatment of olive mill wastewater", Bioresource Technology, 96, 317-322, 2005.

[25] Beccari M., Carucci G., Lanz A.M., Majone M., Petrangeli Papini M., "Removal of molecular weight fractions of COD and phenolic compounds in an integrated treatment of olive oil mill effluents", Biodegradation, 13, 401-410, 2002.

[26] Robles A., Lucas R., de Cienfuegos G.A., Gálvez A., "Biomass production and detoxification of wastewaters from the olive oil industry by strains of penicillium isolated from wastewater disposal ponds", Bioresource Technology, 74, 217-221, 2000.

[27] Gernjak W., Maldonado M.I., Malato S., Cáceres J., Krutzler T., Glaser A., Bauer R., "Pilotplant treatment of olive mill wastewater $(\mathrm{OMW})$ by solar $\mathrm{TiO}_{2}$ photocatalysis and solar photofenton”, Solar Energy, 77, 567-572, 2004.

[28] Paredes C., Cegarra J., Bernal M.P., Roig A., "Influence of olive mill wastewater in composting and impact of the compost on a swiss chard crop and soil properties", Environment International, 31, 305-312, 2005.

[29] Borja R., Rincón B., Raposo F., Alba J., Martín A., “A study of anaerobic digestibility of twophases olive mill solid waste (OMSW) at mesophilic temperature", Process Biochemistry, 38, 733-742, 2002.

[30] Kapellakis I.E., Tsagarakis K.P., Crowther J.C., “ Olive oil history, production and by-product management”, Rev Environ Sci Biotechnol, 7, 1-26, 2008.

[31] Israilides C.J., Vlyssides A.G., Mourafeti V.N., Karvouni G., "Olive oil wastewater treatment with the use of an electrolysis system”, Bioresource Technology, 61, 2, 163-170, 1997.

[32] Aggelis G.G., Gavala H.N., Lyberatos G., "Combined and separate aerobic and anaerobic biotreatment of green olive debittering wastewater", Journal of Agricultural Engineering Research, 80(3), 283-292, 2001.

[33] DEÜ, Zeytin Karasuyu Arıtımı Projesi: EBSO Projesi Kapsamındaki Zeytinyağı İşletmeleri İçin Durum Tespiti, Karasu Karakterizasyonu, Karasu Arıtılabilirlik Çalışmaları ve Sonuçları”, DEÜ Mühendislik Fakültesi Çevre Mühendisliği Bölümü, İzmir, 2003.

[34] Ergüder T.H., Güven E., Demirer G.N., “Anaerobic treatment of olive mill wastes in batch reactors", Process Biochemistry, 36, 243-248, 2000.

[35] Borja R., Alba J., Banks C.J., "Anaerobic digestion of wash waters derived from the purification of virgin olive oil using a hybrid reactor combining a filter and a sludge blanket", Process Biochemistry, 31, 3, 219-224, 1996.

[36] Benitez F.J., Beltran-Heredia J., Torregrosa J., Acero J.L., "Treatment of olive mill wastewaters by ozonation, aerobic degradation and the combination of both treatments", Journal of Chemical Technology and Biotechnology, 74, 639-646, 1999.

[37] Fountoulakis M.S., Dokianakis S.N., Kornaros M.E., Aggelis G.G., Lyberatos, G., "Removal of phenolics in olive mill wastewaters using the white-rot fungus, Pleurotus Ostreatus", Water Research, 36, 4735-4744, 2002. 
[38] Lamia A., Moktar H., "Fermentative decolorization of olive mill wastewater by LactobacillusPlantarum”, Process Biochemistry, 39, 59-65, 2003.

[39] González-González A., Cuadros F., "Effect of aerobic pretreatment on anaerobicdigestion of olive mill wastewater (OMWW): An ecoefficient treatment, Food and Bioproducts Processing, 95, 339-345, 2015.

[40] Dalis D., Anagnostidis K., Lopez A., Letsiou I., Hartmann L., “Anaerobic digestion of total raw olive-oil wastewater in a two-stage pilot-plant (up-flow and fixed-bed bioreactors)", Bioresource Technology, 57(3), 237-243, 1996.

[41] Marques I.P., “Anaerobic digestion treatment of olive mill wastewater for effluent re-use in irrigation", Desalination, 137, 233-239, 2001.

[42] Gizgis N., Georgiou M., Diamadopoulos E., "Sequential anaerobic/aerobic biological treatment of olive mill wastewater and municipal wastewater", Journal of Chemical Technology and Biotechnology, 81, 1563-1569, 2006.

[43] Jarboui R., Sellami F., Azri C., Gharsallah N., Ammar E., "Olive mill wastewater evaporation management using PCA method case study of natural degradation in stabilization ponds (Sfax, Tunisia)”, Journal of Hazardous Materials, 176(1-3), 992-1005, 2010.

[44] Roig A., Cayuela M.L., Sánchez-Monedero M.A. , “An overview on olive mill wastes and their valorisation methods”, Waste Management, 26, 960-969, 2006.

[45] Aly A.A., Hasan Y.N.Y., Al-Farraj A.S, "Olive mill wastewater treatment using a simple zeolitebased low-cost method, Journal of Environmental Management, 145, 341-348, 2014.

[46] Jarboui R., Sellami F., Kharroubi A., Gharsallah N., Ammar E., "Olive mill wastewater stabilization in open-air ponds: impact on clay-sandy soil”, Bioresource Technology, 99(16), 7699-7708, 2008.

[47] Meyssami B., Kasaeian A.B., "Use of coagulants in treatment of olive oil wastewater model solutions by induced air flotation”, Bioresource Technology, 96, 303-307, 2005.

[48] Sarika R., Kalogerakis N., Mantzavinos D., "Treatment of olive mill effluents, Part II. Complete removal of solids by direct flocculation with poly-electrolytes", Environment International, 31, 297-304, 2005.

[49] Papaphilippou P.C., Yiannapas C., Politi M., Daskalaki V.M., Michael C., Kalogerakis N., Mantzavinos D., Fatta-Kassinos D., "Sequential coagulation-flocculation, solvent extraction and photo-Fenton oxidation for the valorization and treatment of olive mill effluent", Chemical Engineering Journal, 224, 82-88, 2013.

[50] Al-Malah K., Azzam M.O.J., Abu-Lail N.I., "Olive mills effluent (OME) wastewater posttreatment using activated clay”, Separation and Purification Technology, 20(2-3), 225-234, 2000 .

[51] Ochando-Pulido J.M., Victor-Ortega M.D., Hodaifa G., Martinez-Ferez A., "Physicochemical analysis and adequation of olive oil mill wastewater after advanced oxidation process for reclamation by pressure-driven membrane technology", Science of the Total Environment, 503504, 113-121, 2015. 
[52] Kiai H., García-Payo M.C., Hafidi A., Khayet M., "Application of membrane distillation technology in the treatment of table olive wastewaters for phenolic compounds concentration and high quality water production" Chemical Engineering and Processing, 86, 153-161, 2014.

[53] El-Abbassi A., Kiai H., Hafidi A., Garcia-Payo M.C., Khayet M., "Treatment of olive mill wastewater by membrane distillation using polytetrafluoroethylene membranes", Separation and Purification Technology, 98, 55-61, 2012.

[54] Ochando-Pulido J.M., Verardo V., Segura-Carretero A., Martinez-Ferez A., "Analysis of the concentration polarization and fouling dynamic resistances under reverse osmosis membrane treatment of olive mill wastewater", Journal of Industrial and Engineering Chemistry, in press, 2015 .

[55] Cassano A., Conidi C., Drioli E., "Comparison of the performance of UF membranes in olive mill wastewaters treatment, Water Research, 45, 3197-3204, 2011.

[56] Zirehpour A., Rahimpour A., Jahanshahi M., Peyravi M., "Mixed matrix membrane application for olive oil wastewater treatment: Process optimization based on Taguchi design method", Journal of Environmental Management, 132, 113-120, 2014.

[57] El-Abbassi A., Kiai H., Raiti J., Hafidi A., “Application of ultrafiltration for olive processing wastewaters Treatment”, Journal of Cleaner Production, 65, 432-438, 2014.

[58] Garcia-Castello, E., Cassano, A., Criscuoli, A., Conidi, C., Drioli, E., "Recovery and concentration of polyphenols from olive mill wastewaters by integrated membrane system", Water Research 44, 3883-3892, 2010.

[59] Cassano A., Conidi C, Giorno L., Drioli E., "Fractionation of olive mill wastewaters by membrane separation techniques", Journal of Hazardous Materials, 248-249, 185-193, 2013.

[60] Coskun T., Debik E., Manav Demir N., "Treatment of olive mill wastewaters by nanofiltration and reverse osmosis membranes", Desalination, 259, 65-70, 2010.

[61] Tezcan-Ün Ü., Uğur S., Koparal A.S., Öğütveren Ü.B., "Electrocoagulation of olive mill wastewaters", Separation and Purification Technology, 52, 136-141, 2006.

[62] Chen, G., "Electrochemical technologies in wastewater treatment", Separation and Purification Technology, 38, 11-41, 2004.

[63] Hanafi F., Assobhei O., Mountadar M., "Detoxification and Discoloration of Moroccan Olive Mill Wastewater", Journal of Hazardous Materials, 174, 807-812, 2010.

[64] Uğurlu M., "Elektrokoagülasyon yöntemi ile kağıt atık sularında bazı inorganik bileşenlerin giderilmesi”, G. ̈. Fen Bilimleri Dergisi, 17(3), 85-99, 2004.

[65] Adhoum N., Monser L., "Decolourization and removal of phenolic compounds from olive mill wastewater by electrocoagulation”, Chemical Engineering and Processing, 43, 1281-1287, 2004.

[66] García-García P., López-López A., Moreno-Baquero J. M., Garrido-Fernández A., “Treatment of wastewaters from the green table olive packaging industry using electro-coagulation", Chemical Engineering Journal, 170, 59-66, 2011. 
[67] Kartal Z., Ölmez Hancı T., Arslan Alaton İ., "Bir zeytinyağı karasuyunun koagülasyon ve elektrokoagülasyon prosesleriyle kimyasal arıtılabilirliğinin incelenmesi”, itüdergisi/E Su Kirlenmesi Kontrolü, 18(2-3), 3-12, 2008.

[68] Khoufi S., Feki F., Sayadi S., "Detoxification of olive mill wastewater by electrocoagulation and sedimentation processes”, Journal of Hazardous Materials, 142, 58-67, 2007.

[69] Çatalkaya E.Ç., Balli U., Şengül F., “Fenol'ün fotokimyasal yöntemlerle parçalanması ve mineralizasyonu”, Su Kirlenmesi Kontrolü Dergisi (SKKD), 14(3), 31-41, 2004.

[70] Arslan-Alaton İ., Gürses F., "Penisilin Prokain G antibiyotik formülasyon atıksuyunun Fentonbenzeri ve Foto-Fenton-benzeri ileri oksidasyon prosesleri ile arıtılabilirliğinin incelenmesi, $\mathbf{S u}$ Kirlenmesi Kontrolü Dergisi (SKKD), 14(1), 11-16, 2004.

[71] Siorou S., Vgenis T.T., Dareioti M.A., Vidali M.-S., Efthimiou I., Kornaros M., Vlastos D., Dailianis S., "Investigation of olive mill wastewater (OMW) ozonation efficiency with the use of a battery of selected ecotoxicity and human toxicity assays", Aquatic Toxicology,164, 135-144, 2015.

[72] Chedeville O., Debacq M., Porte C., "Removal of phenolic compounds present in olive mill wastewaters by ozonation”, Desalination, 249, 865-869, 2009.

[73] Drouice M., Mignot, V.L., Lounici, H., Belhocine, D., Grib H., Pauss A., Mameri N., "A compact process for the treatment of olive mill wastewater by combining UF and $\mathrm{UV} / \mathrm{H}_{2} \mathrm{O}_{2}$ techniques", Desalination, 169, 81-88, 2004.

[74] Birgül A., Solmaz Akal S.K., “Tekstil endüstrisi atıksuları üzerinde ileri oksidasyon ve kimyasal arıtma prosesleri kullanılarak KOİ ve renk giderimi araştırılması”, Ekoloji, 15, 62, 72-80, 2007.

[75] Kallel M., Belaid C., Mechichi T., Ksibi M, Elleuch B., "Removal of organic load and phenolic compounds from olive mill wastewater by fenton oxidation with zero-valent iron", Journal of Hazardous Materials, 163, 550-554, 2009.

[76] Kiril Mert B., Yonar T., Yalili Kilic M., Kestioğlu K., "Pre-treatment studies on olive oil mill effluent using physicochemical, fenton and fenton-like oxidations processes", Journal of Hazardous Materials, 174, 122-128, 2010.

[77] Özdemir C., Tezcan H., Sahinkaya S., Kalipci E., "Pretreatment of olive oil mill wastewater by two different applications of fenton oxidation processes", Clean - Soil, Air, Water, 38(12), $1152-1158,2010$.

[78] Nieto L. M., Hodaifa G., Rodríguez S., Giménez J.A., Ochando J., "Degradation of organic matter in olive-oil mill wastewater through homogeneous Fenton-like reaction", Chemical Engineering Journal, 173, 503-510, 2011.

[79] Hodaifa G., Ochanda-Pulido J.M., Rodriguez-Vives S., Martinez-Ferez A., "Optimization of continuous reactor at pilot scale for olive-oil mill wastewater treatment by Fenton-like process", Chemical Engineering Journal, 220, 117-124, 2013.

[80] Badawy M.I., Gohary F.El., Ghaly M.Y., Ali M.E.M., “ Enhancement of olive mill wastewater biodegradation by homogeneous and heterogeneous photocatalytic oxidation", Journal of Hazardous Materials, 169, 673-679, 2009. 
[81] Gotsi M., Kalogerakis N., Psillakis E., Samaras P., Mantzavinos D., "Electrochemical oxidation of olive oil mill wastewaters", Water Research, 39, 17, 4177-4187, 2005.

[82] Selçuk H., Sarıkaya H.Z., "Fotoelektrokimyasal yöntemle humik asit giderimi”, itüdergisi/d mühendislik, 3(6), 82-90, 2004.

[83] El Hajjouji H., Barje F., Pinelli E., Bailly J.R., Richard C., Winterton P., Revel J.-C., Hafidi M., "Photochemical $\mathrm{UV} / \mathrm{TiO}_{2}$ treatment of olive mill wastewater (OMW)", Bioresource Technology, 99, 7264-7269, 2008.

[84] Gomes H.T., Figueiredo J.L., Faria J.L., "Catalytic wet air oxidation of olive mill wastewater", Catalysis Today, 124, 254-259, 2007.

[85] Yahiaouia O., Lounicia H., Abdia N., Drouichi N., Ghaffour N., Pauss A., Mameri N., "Treatment of olive mill wastewater by the combination of ultrafiltration and bipolar electrochemical reactor processes”, Chemical Engineering and Processing, 50, 37-41, 2011.

[86] Kotsou M., Kyriacou A., Lasaridi K., Pilidis G., "Integrated aerobic biological treatment and chemical oxidation with fenton's reagent for the processing of green table olive wastewater", Process Biochemistry, 39, 1653-1660, 2004.

[87] Zorpas A.A., Costa C.N., "Combination of fenton oxidation and composting for the treatment of the olive solid residue and the olive mill wastewater from the olive oil industry in Cyprus" Bioresource Technology, 101,7984-7987, 2010.

[88] Dhouib A, Aloui F., Hamad N., Sayadi S., "Pilot-plant treatment of olive mill wastewaters by phanerochaete chrysosporium coupled to anaerobic digestion and ultrafiltration", Process Biochemistry, 41, 159-167, 2006.

[89] Khoufi S., Aloui F., Sayadi S., "Pilot scale hybrid process for olive mill wastewater treatment and reuse", Chemical Engineering and Processing, 48, 643-650, 2009. 